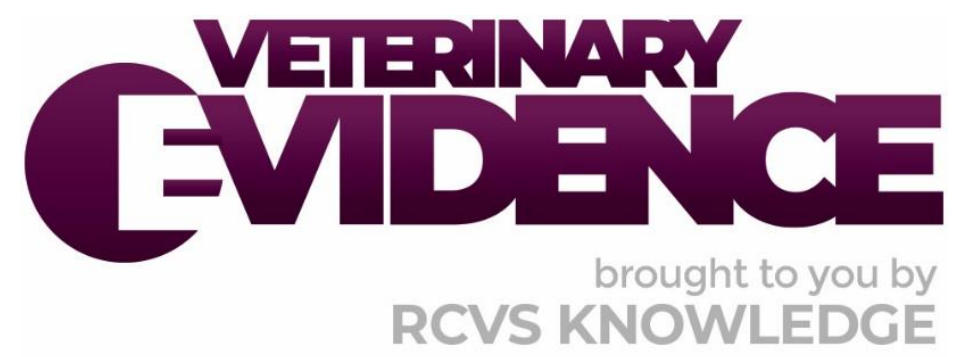

\title{
Does UK licensed NSAID administration reduce signs of postoperative pain in calves castrated without local anaesthesia?
}

\author{
A Knowledge Summary by
}

Alexandra Bartlett BSC (Hons) ${ }^{1^{*}}$

${ }^{1}$ The Royal Veterinary College, Hawkshead Lane, Hatfield, Hertfordshire, AL9 7TA
${ }^{*}$ Corresponding Author (abartlett7@rvc.ac.uk)

There is an erratum to this paper published in Veterinary Evidence Vol 6, Issue 3 (2021): https://doi.org/10.18849/ve.v6i3.525

ISSN: 2396-9776

Published: 08 Jul 2021

in: The Veterinary Evidence journal Vol 6, Issue 3

DOI: https://doi.org/10.18849/ve.v6i3.452

Reviewed by: John Campbell (DVM DVSc) and lain Richards

(BVSc MVetSci MRCVS)

Next Review Date: 08 Apr 2023 


\section{KNOWLEDGE SUMMARY}

There is an erratum to this paper published in Veterinary Evidence Vol 6, Issue 3 (2021): https://doi.org/10.18849/ve.v6i3.525

\section{PICO question}

In calves undergoing castration without local or general anaesthesia, do non-steroidal anti-inflammatory drugs (NSAIDs) licensed for use in cattle in the UK administered either before, during or after the procedure reduce signs of postoperative pain?

\section{Clinical bottom line}

\section{Category of research question}

\section{Treatment}

\section{The number and type of study designs reviewed}

Twenty studies were critically appraised. All were controlled trials, of which 17 were randomised. Only NSAIDs licensed for use in cattle in the UK were included in the search strategy and in appraised papers

\section{Strength of evidence}

Moderate

\section{Outcomes reported}

Five studies reported an improvement in both physiological and behavioural indicators of postcastration pain following NSAID administration and a further eight reported improvements in either physiological or behavioural parameters. Seven studies found no improvements in pain indicators

\section{Conclusion}

There is moderate evidence to suggest that NSAID administration before, during or after castration is able to reduce the signs of postoperative pain in calves castrated without anaesthesia. The degree to which pain is reduced is variable and depends upon factors including but not limited to castration method, specific NSAID given, dosage, administration and calf age

\section{How to apply this evidence in practice}

The application of evidence into practice should take into account multiple factors, not limited to: individual clinical expertise, patient's circumstances and owners' values, country, location or clinic where you work, the individual case in front of you, the availability of therapies and resources.

Knowledge Summaries are a resource to help reinforce or inform decision making. They do not override the responsibility or judgement of the practitioner to do what is best for the animal in their care. 


\section{Clinical scenario}

Calf castration is a common management practice, as it reduces undesirable behaviour (e.g. bullying, mounting and fighting) and castrated calves are easier and less dangerous to handle than bulls (FAWC, 2019). There is also an economic incentive to castration as it prevents unwanted matings producing unplanned/low-value calves and there is a consumer preference for beef from steers compared to bulls (Cooper, 2016). Although castration is undoubtedly painful (Stafford \& Mellor, 2005; and Cooper, 2016), calves under 8 weeks old can legally be castrated without anaesthesia or pain relief; calves older than this must be castrated by a veterinary surgeon with appropriate anaesthesia, however the Farm Animal Welfare Council (FAWC) (2019) report that it is not uncommon for calves older than 8 weeks to be castrated by stock-keepers without adequate anaesthesia. Both the FAWC and the British Veterinary Association (BVA) recommend the use of local anaesthesia and longer-acting analgesia for all castrations and recommend non-steroidal anti-inflammatory drugs (NSAIDs) specifically to manage more chronic pain. NSAID use for disbudding or dehorning is increasing but is still uncommon in castration and despite recognition from veterinary surgeons that castration is painful, adult cattle are more likely than calves to receive analgesia for similarly painful procedures (BVA, 2017; and FAWC, 2019).

While local anaesthesia combined with analgesia is ideal for managing castration pain, local anaesthetics may be less popular with farmers as a time delay must be observed between administration and castration for them to take effect. NSAIDs can be administered either before, during or after castration and there are several licenced for cattle in the UK (meloxicam, ketoprofen, flunixin and carprofen) (Veterinary Medicines Directorate, 2020) so may be more practicable for on-farm use. This Knowledge Summary aims to assess the efficacy of NSAIDs in reducing signs of postoperative pain; use of effective analgesia would improve calf welfare even in the absence of local anaesthesia and could perhaps lead to further improvements e.g. local anaesthesia before castration.

\section{The evidence}

Twenty studies were critically appraised; all were controlled trials and of these 17 were randomised. Only NSAIDs licensed for use in cattle in the UK were included in the search strategy and in appraised papers. Direct comparison between the studies was made difficult by variations in calf age*, castration method, NSAID type, dosage, administration and timing of administration. Many studies also used relatively small sample sizes and did not report power analyses when determining sample size or $\mathrm{Cl}$ when reporting data, possibly reducing the reliability of their results. Additionally, some studies also investigated variables which were not relevant to the PICO question such as pain associated with branding and the effect of local anaesthetic on pain indicators (Laurence et al., 2018; Marti et al., 2018; Meléndez et al., 2018a; Meléndez et al., 2018c; Van Der Saag et al., 2018; and Webster et al., 2013); these studies were included but the treatments not relevant to the PICO question were excluded from the appraisal. Studies assessed pain response to NSAIDs by measuring physiological parameters (e.g. cortisol concentrations, APP concentrations, ADG, scrotal or rectal temperature) and behavioural parameters (e.g. standing, lying and stepping behaviour, motion index, gait, eating and drinking and specific, discrete behaviours such as tail flicking and lesion-licking).

A significant reduction in pain associated with castration was defined as improvements in both physiological and behavioural pain indicators, and no reduction in pain was defined as no significant improvements in either physiological or behavioural indicators. Some studies were ranked as intermediate where there was an improvement in either physiological or behavioural indicators. Five studies (Laurence et al., 2018; Meléndez et al., 2018a; Meléndez et al., 2018b; Olson et al., 2016; and Ting et al., 2003) showed an improvement in both physiological and behavioural indicators, eight studies (Kleinhenz et al., 2018; Meléndez et al., 2018c; Petherick et al., 2014a; Petherick et al., 2014b; Roberts et al., 2015; Roberts et al., 2018; Van Der Saag et al., 2018; and Webster et al., 2013) showed an improvement in one of the physiological or behavioural indicators and seven studies (Daniel et al., 2020; Gellatly et al., 2021; Marti et al., 2018; Moya et al., 2014; Paull et al., 2015; Repenning et al., 2013; and Sutherland et al., 2018) showed no improvement. 
* Regulations that apply to the age at which mandatory use of local anaesthetic is required vary between countries. As pain response varies with age, results from some of the trials reported may be less applicable in a particular country's cattle industry where the calves used in the trial were older than the age at which the use of local anaesthetic is legally required.

\author{
Abbreviations: \\ ADG - average daily (weight) gain \\ APP - acute phase proteins \\ $\mathrm{CBC}$ - complete blood count \\ $\mathrm{Cl}$ - confidence interval \\ $\mathrm{N}: \mathrm{L}$ - neutrophil : lymphocyte ratio \\ SAA - serum amyloid $A$ \\ WBC - white blood cell
}

\title{
Summary of the evidence
}

\begin{tabular}{|c|c|}
\hline \multicolumn{2}{|l|}{ Daniel et al. (2020) } \\
\hline Population: & Approximately 3 month old nursing Angus bull calves (USA) \\
\hline Sample size: & 23 calves \\
\hline Intervention details: & $\begin{array}{l}\text { Treatment groups } \\
\text { 1. No castration control (BULL) } n=6 \text { - chosen based on } \\
\text { phenotype } \\
\text { 2. Band castration without meloxicam (BAN) } n=8 \text { - randomly } \\
\text { assigned } \\
\text { 3. Band castration with meloxicam (BAN }+\mathrm{M}) \mathrm{n}=9 \text { - randomly } \\
\text { assigned } \\
\text { Doses and administration } \\
\text { - Meloxicam ( } 2 \mathrm{mg} / \mathrm{kg} \text { ) administered orally inside gelatin } \\
\text { capsule on days } 0 \text { and } 14 \\
\text { - BULL and BAN given an empty porcine gelatin capsule on } \\
\text { days } 0 \text { and } 14\end{array}$ \\
\hline Study design: & Randomised controlled trial \\
\hline Outcome studied: & $\begin{array}{l}\text { Physiological indicators of pain/inflammation } \\
\text { Objective determination of plasma fibrinogen and serum } \\
\text { haptoglobin concentrations and weight (to determine ADG) before } \\
\text { and after castration } \\
\text { Behavioural indicators of pain } \\
\text { Objective assessment of standing, lying and stepping behaviour and } \\
\text { motion index using accelerometer after castration }\end{array}$ \\
\hline $\begin{array}{l}\text { Main findings: } \\
\text { (relevant to PICO question): }\end{array}$ & $\begin{array}{l}\text { Physiological indicators of pain/inflammation } \\
\text { - Fibrinogen and haptoglobin concentrations were unaffected } \\
\text { by meloxicam administration } \\
\text { - No difference in ADG between BAN and BAN + M groups } \\
\text { Behavioural indicators of pain/inflammation } \\
\text { - BAN + M group took fewer steps than BAN group on days } 7 \\
\text { and } 15 \text { and had significantly more lying bouts per day on } \\
\text { days } 13 \text { and } 14 \text { than BAN group } \\
\text { - Overall meloxicam administration did not result in major } \\
\text { improvements in behavioural pain indicators }\end{array}$ \\
\hline
\end{tabular}




\begin{tabular}{|c|c|}
\hline Limitations: & $\begin{array}{l}\text { - Small sample size may reduce reliability of data (no power } \\
\text { analysis reported) } \\
\text { - No Cl reported } \\
\text { - } \quad \text { onn-blinded study (but behaviour was assessed using } \\
\text { accelerometers so lack of blinding may have had less effect) } \\
\text { Blood samples were taken on days } 0 \text { (before treatment), } 14 \\
\text { and } 28 \text { which may have been too infrequent to observe } \\
\text { short-term changes in fibrinogen and haptoglobin } \\
\text { concentrations, especially during the acute inflammatory } \\
\text { period within the first } 14 \text { days following castration } \\
\text { - Unknown when on day } 0 \text { meloxicam was administered, i.e. } \\
\text { before, concurrently to or after castration } \\
\text { - Unclear significance of BAN + M group taking fewer steps } \\
\text { than BAN group - BULL group took the most steps per day } \\
\text { overall which would suggest that more steps is indicative of } \\
\text { less pain but this could also have been due to cows in the } \\
\text { pasture being in oestrus which was not measured in the } \\
\text { study } \\
\text { Relatively few physiological and behavioural indicators of } \\
\text { pain assessed }\end{array}$ \\
\hline
\end{tabular}

Gellatly et al. (2021)

\begin{tabular}{|c|c|}
\hline Population: & 2 month old Angus and Angus crossbred bull calves (Canada) \\
\hline Sample size: & 131 calves \\
\hline Intervention details: & $\begin{array}{l}\text { Treatment groups } \\
\text { 1. Sham castration with meloxicam (CT-M) } n=24 \\
\text { 2. Sham castration with lactated ringers solution CT-NM) } n=23 \\
\text { 3. Band castration with meloxicam (BA-M) } n=23 \\
\text { 4. Band castration with lactated ringers solution (BA-NM) } n= \\
23 \\
\text { 5. Knife castration with meloxicam (KN-M) } n=18 \\
\text { 6. Knife castration with lactated ringers solution (KN-NM) } n= \\
\quad 20 \\
\text { Subsets of cow-calf pairs representing each treatment group were } \\
\text { randomly selected to be used for behavioural analyses - } 20 \text { calves } \\
\text { were assessed for behavioural changes, } 15 \text { calves were used to } \\
\text { assess cow-calf proximity and } 36 \text { calves were used to measure home } \\
\text { range. } \\
\text { Doses and administration } \\
\text { - Meloxicam ( } 0.5 \mathrm{mg} / \mathrm{kg} \text { ) - subcutaneous injection (timing of } \\
\text { - administration not mentioned) } \\
\text { injection (timing of administration not mentioned) }\end{array}$ \\
\hline Study design: & Randomised controlled trial \\
\hline Outcome studied: & $\begin{array}{l}\text { Physiological indicators of pain/inflammation } \\
\text { - Objective assessment of pain sensitivity before and after } \\
\text { castration - maximum pressure exerted before animal } \\
\text { responded }\end{array}$ \\
\hline
\end{tabular}




\begin{tabular}{|c|c|}
\hline & $\begin{array}{l}\text { - Objective assessment of maximum scrotal temperature and } \\
\text { weight (to determine ADG) before and after castration } \\
\text { - Subjective assessment of wound swelling and wound healing } \\
\text { before and after castration } \\
\text { Behavioural indicators of pain } \\
\text { - Subjective assessment of behaviours inc. suckling, lying, } \\
\text { walking, lesion-licking, foot stamping and tail licking before } \\
\text { and after castration (interobserver reliability = } 0.93 \text { and } \\
\text { intra-observer reliability = 0.90) } \\
\text { - Objective assessment of cow-calf proximity (after castration) } \\
\text { and home range (daily before and after castration) }\end{array}$ \\
\hline $\begin{array}{r}\text { Main findings: } \\
\text { (relevant to PICO question): }\end{array}$ & $\begin{array}{l}\text { Physiological indicators of pain and inflammation } \\
\text { No effect of meloxicam on ADG, pain sensitivity, maximum scrotal } \\
\text { temperature, wound swelling or wound healing }(95 \% \mathrm{Cl} \text { reported for } \\
\text { wound swelling and healing) } \\
\text { Behavioural indicators of pain } \\
\text { - Meloxicam treated calves spent more time suckling than } \\
\text { non-treated calves }(p<0.05) \\
\text { - No effect of meloxicam on other behavioural parameters or } \\
\text { cow-calf proximity }\end{array}$ \\
\hline Limitations: & $\begin{array}{l}\text { - Small sample sizes used to assess behavioural changes }(n= \\
\text { 20), cow-calf proximity ( } n=15) \text { and home range }(n=36)- \\
\text { no power analyses reported } \\
\text { - } \quad \text { Behavioural data was not collected for one group of } 12 \\
\text { calves for the first } 2 \text { hours following castration due to } \\
\text { environmental conditions so acute pain signs may not have } \\
\text { been identified } \\
\text { - } 13 \text { calves were removed from the study, reducing sample } \\
\text { sizes for behavioural assessments (only two calves for each } \\
\text { knife-castrated group were assessed compared to four } \\
\text { calves for each other treatment group) } \\
\text { - Small magnitude of difference in suckling time between } \\
\text { meloxicam treated and untreated calves may lack biological } \\
\text { significance } \\
\text { - Cow-calf proximity may not be an adequate indicator of pain } \\
\text { - Non-blinded trial } \\
\text { - Timing of meloxicam or placebo dose was not given } \\
\text { Relatively limited physiological assessment (e.g. no } \\
\text { assessment of cortisol or APP) } \\
\text { No Cl reported for outcomes other than wound swelling and } \\
\text { healing, which is not directly related to pain }\end{array}$ \\
\hline
\end{tabular}

Kleinhenz et al. (2018)

\begin{tabular}{|c|c|}
\hline Population: & 9 month old Holstein calves (USA) \\
\hline Sample size: & 23 calves ( 16 bulls and 7 steers) \\
\hline Intervention details: & $\begin{array}{l}\text { Treatment groups } \\
\text { 1. Surgical castration with placebo (CAST }+ \text { PLBO) } n=8 \\
\text { 2. Surgical castration with flunixin (CAST }+ \text { FLU) } n=8 \\
\text { 3. Sham castration with placebo (steers) (SHAM + PLBO) } n=7\end{array}$ \\
\hline
\end{tabular}




\begin{tabular}{|c|c|}
\hline & $\begin{array}{l}\text { Study personnel were blinded to treatment groups for castrated } \\
\text { calves } \\
\text { Doses and administration } \\
\text { - Flunixin meglumine ( } 3.33 \mathrm{mg} / \mathrm{kg} \text { ) - applied topically to the } \\
\text { back from the shoulders to the tailhead } \\
\text { - Placebo (propylene glycol, isopropyl alcohol and red dye to } \\
\text { mimic colour, viscosity and odour of flunixin) - applied in } \\
\text { equal volume to the flunixin and in the same area } \\
\text { - Flunixin and placebo were administered concurrently with } \\
\text { castration }\end{array}$ \\
\hline Study design: & Randomised controlled trial \\
\hline Outcome studied: & $\begin{array}{l}\text { Physiological indicators of pain/inflammation } \\
\text { Objective analysis of plasma cortisol and substance P concentrations } \\
\text { and ocular temperature using infrared thermography before and } \\
\text { after castration } \\
\text { Behavioural indicators of pain } \\
\text { Objective analysis of gait (step force, step pressure and stride } \\
\text { length) before and after castration }\end{array}$ \\
\hline $\begin{array}{l}\text { Main findings: } \\
\text { (relevant to PICO question): }\end{array}$ & $\begin{array}{l}\text { Physiological indicators of pain/inflammation } \\
\text { - } \text { CAST + FLU had lower mean cortisol concentrations } 2,3 \text { and } \\
4 \text { hours postcastration than CAST + PLBO, suggesting flunixin } \\
\text { controls the initial cortisol spike associated with castration } \\
\text { and longer-term cortisol levels } \\
\text { - } \text { CAST + FLU ( } 73 \mathrm{ng} \times \mathrm{h} / \mathrm{ml}(95 \% \mathrm{Cl} 45-102)) \text { had smaller } \\
\text { cortisol area under the curve than CAST + PLBO up to } 8 \\
\text { hours postcastration ( } 157 \mathrm{ng} \times \mathrm{h} / \mathrm{ml}(95 \% \mathrm{Cl} 128-186)) \\
\text { - } \text { No effect of flunixin on substance P concentrations } \\
\text { - CAST + FLU had higher maximum, mean and minimum } \\
\text { ocular temperatures than CAST + PLBO and SHAM + PLBO } \\
\text { following castration and treatment (authors hypothesised } \\
\text { reduced ocular temperature with flunixin) } \\
\text { Behavioural indicators of pain } \\
\text { CAST + PLBO and CAST + FLU placed more force on front } \\
\text { limbs than SHAM + PLBO, suggesting gait modification in } \\
\text { response to castration pain; CAST + FLU had a numerically } \\
\text { smaller mean force difference between fore- and hindlimbs } \\
\text { than CAST + PLBO } \\
\text { SHAM + PLBO had a lower total impulse (i.e. traveled more } \\
\text { quickly) than CAST + PLBO and CAST + FLU but no significant } \\
\text { difference between CAST + PLBO and CAST + FLU } \\
\text { No significant difference in stride lengths between } \\
\text { treatment groups }\end{array}$ \\
\hline Limitations: & $\begin{array}{l}\text { - Small sample size may reduce reliability of data (no power } \\
\text { analysis for sample size reported) } \\
\text { - First ocular temperature reading was taken } 2 \text { hours } \\
\text { postcastration preventing measurement of acute changes } \\
\text { before this; ocular temperature measurement as pain } \\
\text { assessment is not well understood and optimal sampling } \\
\text { intervals are not well described }\end{array}$ \\
\hline
\end{tabular}




\begin{tabular}{|l|l|}
\hline - & Blood samples were taken on days $-6,-1,0$ (cortisol only), \\
$1,2,6,10$ and $13-$ these sampling intervals may have been \\
too wide to detect some changes, especially in the acute \\
phase immediately following castration \\
- $\begin{array}{l}\text { Some calves were too large for the pressure mats - } \\
\text { complete strides and two footfalls per timepoint could not } \\
\text { be recorded for each calf, limiting stride length evaluation } \\
\text { Calves were only studied for } 72 \text { hours postcastration so } \\
\text { longer-term pain responses were not investigated, although } \\
\text { due to its kinetics, flunixin was unexpected to affect pain } \\
\text { responses past this time } \\
\text { Behavioural assessment of pain was limited and only } \\
\text { included gait parameters rather than e.g. standing, lying and } \\
\text { postural behaviour }\end{array}$ \\
\hline
\end{tabular}

Laurence et al. (2018)

\begin{tabular}{|c|c|}
\hline Population: & 6-8 month old Brahman bulls (Australia) \\
\hline Sample size: & 48 calves \\
\hline Intervention details: & 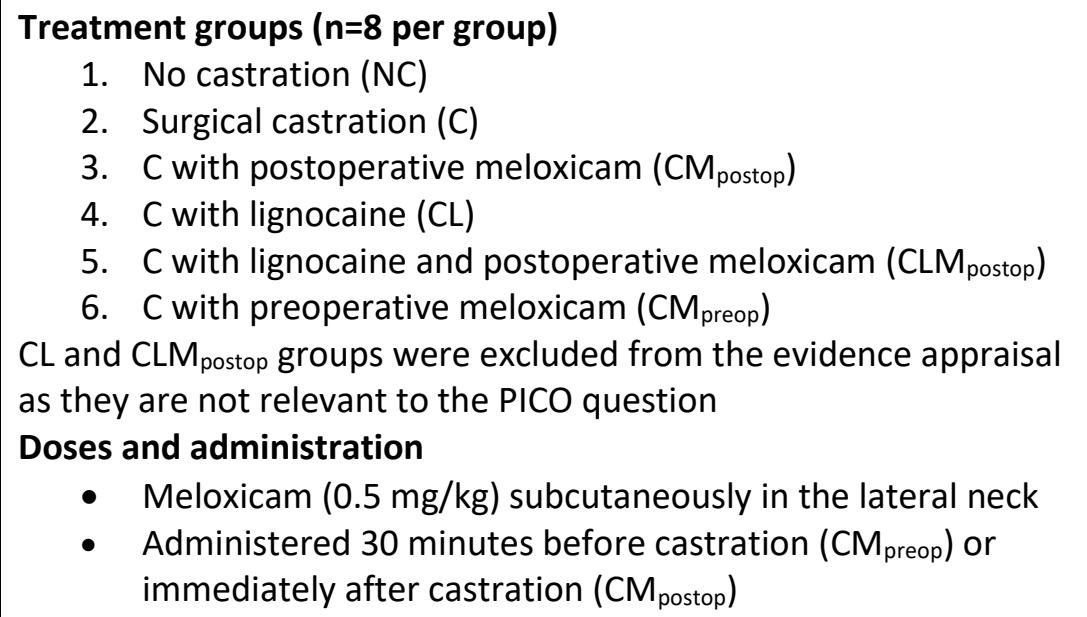 \\
\hline Study design: & Randomised controlled trial \\
\hline Outcome studied: & $\begin{array}{l}\text { Physiological indicators of pain/inflammation } \\
\text { Objective assessment of liveweight change and serum cortisol } \\
\text { concentrations on days }-6,-1,1,2,6,10,13 \text {; serum cortisol was } \\
\text { also measured immediately before castration } \\
\text { Behavioural indicators of pain } \\
\text { - Subjective assessment of crush score (observing the animal } \\
\text { for } 60 \text { seconds in the crush without head restraint), } \\
\text { recorded on days }-6,-1,1,2,6,10,13 \\
\text { - Subjective assessment of baulk score by a single observer } \\
\text { when entering the weighing area for the first time (recorded } \\
\text { on days -6, }-1,1,2,6,10,13 \text { ) } \\
\text { Non-baulker - enters voluntarily when the gate } \\
\text { opens, or a light tap on the rump is required for the } \\
\text { animal to enter } \\
\text { Baulker - a hard slap on the rump or tail twisting is } \\
\text { required for the animal to enter }\end{array}$ \\
\hline
\end{tabular}




\begin{tabular}{|c|c|}
\hline & $\begin{array}{l}\text { - Objective assessment of step count, number and duration of } \\
\text { recumbent periods and total resting time using pedometers } \\
\text { (recorded daily) } \\
\text { 1. Calm, no movement } \\
\text { 2. Slightly restless } \\
\text { 3. Squirming and occasionally shaking the squeeze } \\
\text { chute } \\
\text { 4. Very vigorous and continuous movement and } \\
\text { shaking of the squeeze chute } \\
\text { 5. Rearing, twisting body, struggling violently }\end{array}$ \\
\hline $\begin{array}{l}\text { Main findings: } \\
\text { (relevant to PICO question): }\end{array}$ & $\begin{array}{l}\text { Physiological indicators of pain/inflammation } \\
\text { - } \mathrm{CM}_{\text {postop }} \text { group had significantly higher average weights than } \\
\mathrm{C} \text { group and were not significantly different from NC calves } \\
\text { - } \mathrm{CM}_{\text {postop }} \text { and } \mathrm{CM}_{\text {preop }} \text { calves had significantly lower plasma } \\
\text { cortisol concentrations than } \mathrm{C} \text { calves } \\
\text { - } \mathrm{C} \text { calves had highest cortisol concentrations of all treatment } \\
\text { groups } \\
\text { Behavioural indicators of pain } \\
\text { - } \mathrm{CM}_{\text {preop }} \text { calves were significantly more active and } \mathrm{CM}_{\text {postop }} \\
\text { calves rested less than all other groups on day } 1 \\
\text { - All castrated animals had significantly shorter rest durations } \\
\text { than NC calves } \\
\text { - No difference in baulk and crush scores between treatment } \\
\text { groups }\end{array}$ \\
\hline Limitations: & $\begin{array}{l}\text { - Small sample sizes per treatment group may have made } \\
\text { associations more difficult to detect (no power analyses } \\
\text { reported) } \\
\text { - } \quad \text { No Cl reported } \\
\text { - Behavioural indicators of pain may have been difficult to } \\
\text { identify as the cattle used were extensively managed and } \\
\text { unused to human contact so more likely to mask pain signs } \\
\text { - } \quad \text { Relatively limited physiological parameters assessed } \\
\text { - Non-blinded trial } \\
\text { - } \text { mo placebo given for animals not given one or more of the } \\
\text { medical treatments }\end{array}$ \\
\hline
\end{tabular}

Marti et al. (2018)

\begin{tabular}{|r|l|}
\hline Population: & 2 month old Angus crossbred bull calves (Canada) \\
\hline Sample size: & 72 calves \\
\hline Intervention details: & Treatment groups (exact numbers per group not stated) \\
& 1. Sham control with lactated Ringer's solution (CN-NM) \\
& 2. Sham control with meloxicam (CN-M) \\
& 3. Surgical castration with lactated Ringer's solution (KN-NM) \\
& 4. Surgical castration with meloxicam (KN-M) \\
& 6. Surgical castration and branding with lactated Ringer's \\
& KB groups were excluded from the evidence appraisal as branding is \\
& not relevant to the PICO question \\
\hline
\end{tabular}




\begin{tabular}{|c|c|}
\hline & $\begin{array}{l}\text { Doses and administration } \\
\text { - Meloxicam }(0.5 \mathrm{mg} / \mathrm{kg}) \text { administered subcutaneously } \\
\text { immediately before castration } \\
\text { - Lactated Ringer's solution administered subcutaneously } \\
\text { immediately before castration at an equivalent volume to } \\
\text { meloxicam }\end{array}$ \\
\hline Study design: & Randomised controlled trial \\
\hline Outcome studied: & $\begin{array}{l}\text { Physiological indicators of pain/inflammation } \\
\text { - Objective assessment of forehead hair cortisol } \\
\text { concentration, serum haptoglobin and SAA concentrations, } \\
\text { maximum scrotal temperature and circumference before } \\
\text { and after castration } \\
\text { - Objective assessment of weight before and after castration } \\
\text { to determine ADG } \\
\text { Behavioural indicators of pain } \\
\text { - Objective measurement of total standing and lying time, } \\
\text { duration (mean time spend standing/lying per bout) and } \\
\text { bouts (individual standing/lying bouts) using accelerometers } \\
\text { and stride length before and after castration } \\
\text { - Subjective assessment of suckling, tail flicking, foot } \\
\text { stamping, head turning and lesion-licking using video } \\
\text { footage from } 7 \text { days after castration }\end{array}$ \\
\hline $\begin{array}{l}\text { Main findings: } \\
\text { (relevant to PICO question): }\end{array}$ & $\begin{array}{l}\text { Physiological indicators of pain/inflammation } \\
\text { - No effect of meloxicam treatment on ADG, hair cortisol } \\
\text { - } \text { KN-M contrations, haptoglobin or SAA concentration } \\
\text { circumference compared to KN-NM calves } \\
\text { Behavioural indicators of pain } \\
\text { - No treatment differences for all groups seen for stride } \\
\text { length, standing and lying duration or standing and lying } \\
\text { bouts } \\
\text { - CN calves spent less total time lying than KN-NM and KN-M } \\
\text { calves but the time difference between groups was less than } \\
1 \text { hour per day } \\
\text { - No effect of meloxicam treatment was observed for pain- } \\
\text { related behaviours }\end{array}$ \\
\hline Limitations: & $\begin{array}{l}\text { - Forehead hair contains less cortisol than e.g. tail hair; long } \\
\text { sampling time ( } 42 \text { days) may have made cortisol detection } \\
\text { more difficult as longer hair growth postcastration means } \\
\text { that a smaller proportion of the hair shaft contains } \\
\text { castration-related cortisol } \\
\text { - Sub-optimal sampling times for haptoglobin and SAA } \\
\text { (samples collected on days }-1,0 \text { and weekly thereafter) so } \\
\text { acute changes immediately following castration would not } \\
\text { have been seen } \\
\text { - Non-blinded trial } \\
\text { - } 95 \% \text { Cl only stated for wound healing score and not for any } \\
\text { parameters related to pain assessment } \\
\text { - Power analyses for sample sizes not stated }\end{array}$ \\
\hline
\end{tabular}




\begin{tabular}{|c|c|}
\hline Population: & Angus crossbred bull calves aged 67-87 days old (Canada) \\
\hline Sample size: & 71 calves \\
\hline Intervention details: & $\begin{array}{l}\text { Treatment groups } \\
\text { 1. Sham control with lactated Ringer's solution (CT-NM) } n=11 \\
\text { 2. Sham control with meloxicam (CT-M) } n=12 \\
\text { 3. Surgical castration with lactated Ringer's solution (KN-NM) } \\
n=12 \\
\text { 4. Surgical castration with meloxicam (KN-M) } n=12 \\
\text { 5. Surgical castration and branding with lactated Ringer's } \\
\text { solution (BK-NM) } n=12 \\
\text { 6. Surgical castration and branding with meloxicam (BK-M) } \\
n=12\end{array}$ \\
\hline
\end{tabular}

BK groups were not included in evidence appraisal as branding is not relevant to the PICO question

Doses and administration

- Meloxicam $(0.5 \mathrm{mg} / \mathrm{kg})$ - subcutaneously immediately before castration

- Lactated Ringer's solution - administered subcutaneously at equivalent volume to the meloxicam immediately before castration

\begin{tabular}{|c|c|}
\hline Study design: & Randomised controlled trial \\
\hline Outcome studied: & $\begin{array}{l}\text { Physiological indicators of pain/inflammation } \\
\text { - Objective measurement of salivary cortisol concentration, } \\
\text { blood parameters (substance P, SAA, haptoglobin and CBC), } \\
\text { scrotal and rectal temperature and weight (to determine } \\
\text { ADG) before and after castration } \\
\text { - Objective assessment of scrotal circumference after } \\
\text { castration } \\
\text { Behavioural indicators of pain } \\
\text { - Subjective measurement of frequency of tail flicks, foot } \\
\text { stamping, head turning and lesion-licking and duration of } \\
\text { eating, lying, standing and walking after castration by } \\
\text { blinded observers using video footage (inter- and intra- } \\
\text { observer reliability = } 0.95 \text { and } 0.91 \text { respectively) } \\
\text { Objective measurement of stride length by blinded } \\
\text { observers and of standing and lying behaviour using } \\
\text { accelerometers before and after castration }\end{array}$ \\
\hline $\begin{array}{l}\text { Main findings: } \\
\text { (relevant to PICO question): }\end{array}$ & $\begin{array}{l}\text { Physiological indicators of pain/inflammation } \\
\text { - No effect of meloxicam administration on salivary cortisol, } \\
\text { plasma substance P or SAA concentrations } \\
\text { KN-M calves had lower serum haptoglobin concentrations } \\
\text { than KN-NM calves on days 1-2 but had higher haptoglobin } \\
\text { concentrations than KN-NM calves on day } 7 \text { (possibly due to } \\
\text { meloxicam wearing off) } \\
\text { - KN-M calves had lower WBC count on days } 1 \text { and } 2 \text { and } \\
\text { lower N:L on day } 2 \text { than KN-NM (but all values remained } \\
\text { within reference intervals) }\end{array}$ \\
\hline
\end{tabular}




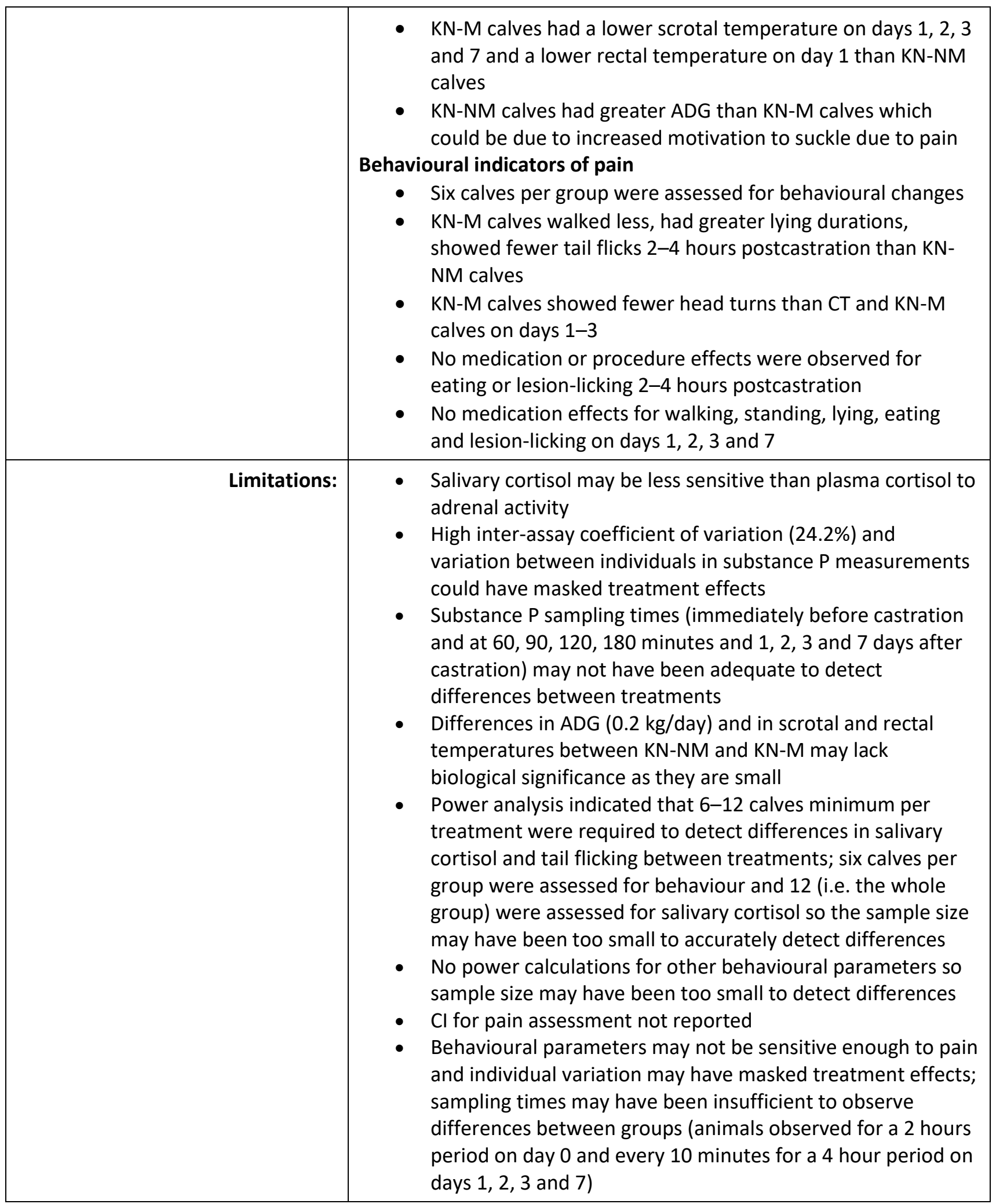

Meléndez et al. (2018b)

\begin{tabular}{|r|l|}
\hline Population: & $7-8$ day old Angus crossbred bull calves (Canada) \\
\hline Sample size: & 72 calves \\
\hline Intervention details: & $\begin{array}{c}\text { Treatment groups ( } \mathbf{n}=\mathbf{1 2} \text { for each group) } \\
\text { 1. Sham castration with no meloxicam (CT-NM) }\end{array}$ \\
\hline
\end{tabular}




\begin{tabular}{|c|c|}
\hline & $\begin{array}{l}\text { 2. Sham castration with meloxicam (CT-M) } \\
\text { 3. Band castration with no meloxicam (BA-NM) } \\
\text { 4. Band castration with meloxicam (BA-M) } \\
\text { 5. Knife castration with no meloxicam (KN-NM) } \\
\text { 6. Knife castration with meloxicam (KN-M) } \\
\text { Doses and administration } \\
\text { - Meloxicam }(0.5 \mathrm{mg} / \mathrm{kg} \text { ) administered subcutaneously } \\
\text { - Single subcutaneous injection of lactated Ringer's solution in } \\
\text { all NM calves }\end{array}$ \\
\hline Study design: & Randomised controlled trial \\
\hline Outcome studied: & $\begin{array}{l}\text { Physiological indicators of pain/inflammation } \\
\text { Objective assessment of salivary cortisol concentration, blood } \\
\text { parameters (substance } P \text {, haptoglobin, SAA, CBC), scrotal and rectal } \\
\text { temperatures and ADG before and after castration } \\
\text { Behavioural indications of pain } \\
\text { - Subjective assessment by blinded observers using video } \\
\text { footage of standing, walking, lying, suckling behaviour and } \\
\text { frequency of tail flicking, head turning, lesion-licking and } \\
\text { foot stamping before and after castration (intra- and } \\
\text { interobserver reliability = } 0.90 \text { and } 0.91 \text { respectively) } \\
\text { - Objective assessment of stride length and standing and lying } \\
\text { behaviour before and after castration }\end{array}$ \\
\hline $\begin{array}{l}\text { Main findings: } \\
\text { (relevant to PICO question): }\end{array}$ & $\begin{array}{l}\text { Physiological indicators of pain/inflammation } \\
\text { - M calves had lower substance P concentrations than NM } \\
\text { calves } 7 \text { days postcastration; also tended }(p=0.06) \text { to be } \\
\text { lower } 3 \text { days postcastration } \\
\text { - M calves had lower WBC count than NM calves } \\
\text { - KN-NM calves had higher SAA concentrations than all other } \\
\text { groups apart from BA-M where there was no difference } \\
\text { Behavioural indicators of pain } \\
\text { - Six calves per treatment group were assessed for } \\
\text { behavioural changes } \\
\text { - NM calves showed more tail flicks than M calves } 2-4 \text { hours } \\
\text { postcastration but M calves showed more tail flicks than NM } \\
\text { calves on day } 7 \text { postcastration (thought to be due to effects } \\
\text { of meloxicam wearing off) } \\
\text { - Tendency for M to have fewer standing bouts, greater lying } \\
\text { duration and longer lying bouts than NM calves } \\
\text { M calves spent less time in lateral recumbency than NM } \\
\text { calves on day } 3\end{array}$ \\
\hline Limitations: & $\begin{array}{l}\text { - Not all findings were associated with } \mathrm{p}<0.05 \text { and were } \\
\text { tendencies rather than statistically significant associations } \\
\text { - Numerical differences in standing and lying bouts are small } \\
\text { and may lack biological significance } \\
\text { - Only six calves per treatment were assessed for behavioural } \\
\text { changes } \\
\text { - No power calculations for sample sizes required so sample } \\
\text { sizes may have been too small to accurately detect } \\
\text { differences between treatment groups } \\
\text { - No } \mathrm{Cl} \text { reported for pain assessment }\end{array}$ \\
\hline
\end{tabular}




\begin{tabular}{|c|c|}
\hline eléndez et al. (2018c) & \\
\hline Population: & 7-8 month old Angus crossbred beef calves (Canada) \\
\hline Sample size: & 48 calves \\
\hline Intervention details: & $\begin{array}{l}\text { Treatment groups } \\
\text { 1. Surgical castration without meloxicam or lidocaine (NR) } \\
n=12 \\
\text { 2. Surgical castration with lidocaine only }(\mathrm{NL}) \mathrm{n}=12 \\
\text { 3. Surgical castration with meloxicam only (MR) } \mathrm{n}=12 \\
\text { 4. Surgical castration with meloxicam and lidocaine (ML) } \mathrm{n}=12 \\
\mathrm{NL} \text { and } \mathrm{ML} \text { groups were not included in the evidence appraisal as } \\
\text { local anaesthesia is not relevant to the PICO question } \\
\text { Doses and administration } \\
\text { - Meloxicam ( } 0.5 \mathrm{mg} / \mathrm{kg} \text { ) - administered subcutaneously in } \\
\text { the neck immediately after the lidocaine/sham block } 30 \\
\text { minutes before castration } \\
\text { - Sham block (MR, NR) consisted of lactated Ringers solution } \\
\text { injected into each spermatic cord and subcutaneously } \\
\text { around the neck of the scrotum } \\
\text { - Calves not given meloxicam were given a single } \\
\text { subcutaneous injection of lactated Ringer's solution }\end{array}$ \\
\hline Study design: & Randomised controlled trial \\
\hline Outcome studied: & $\begin{array}{l}\text { Physiological markers of pain/inflammation } \\
\text { - Objective assessment of saliva and hair cortisol, blood } \\
\text { parameters (SAA, haptoglobin and WBC count), scrotal area } \\
\text { temperature and rectal temperature before and after } \\
\text { castration } \\
\text { - Objective assessment of scrotal circumference after } \\
\text { castration } \\
\text { - Objective assessment of weight before and after castration } \\
\text { to determine ADG } \\
\text { Behavioural indicators of pain } \\
\text { - Subjective assessment by blinded assessors using video } \\
\text { footage of pain-associated behaviour postcastration (tail } \\
\text { flicks, foot stamping, head turning, lesion-licking and } \\
\text { duration of standing, lying, walking and eating) after } \\
\text { castration } \\
\text { - Objective assessment of feeding behaviour (measurement } \\
\text { period not stated) } \\
\text { Objective assessment of stride length and standing and lying } \\
\text { behaviour before and after castration } \\
\text { Plasma meloxicam concentrations and behavioural and escape } \\
\text { responses during castration were also measured; these results were } \\
\text { not appraised as they are not relevant to the PICO question }\end{array}$ \\
\hline $\begin{array}{l}\text { Main findings: } \\
\text { (relevant to PICO question): }\end{array}$ & $\begin{array}{l}\text { Physiological indicators of pain/inflammation } \\
\text { - Salivary cortisol concentrations were lower in MR calves } \\
\text { than NR calves } 2,4 \text { and } 48 \text { hours postcastration but no } \\
\text { differences between groups in hair cortisol concentrations }\end{array}$ \\
\hline
\end{tabular}




\begin{tabular}{|c|c|}
\hline & $\begin{array}{l}\text { - Haptoglobin concentrations were lower in MR calves than } \\
\text { NR calves } 24 \text { and } 48 \text { hours postcastration } \\
\text { - } \text { WBC count was lower in MR calves than NR calves } 24 \text { hours } \\
\text { postcastration } \\
\text { - Scrotal temperature was lower in MR calves than NR calves } \\
24 \text { hours postcastration } \\
\text { Behavioural indicators of pain } \\
\text { - Six calves per group were assessed for behavioural } \\
\text { - indicators of pain } \\
\text { No significant difference reported in observed behavioural } \\
\text { pain markers between NR and MR calves }\end{array}$ \\
\hline Limitations: & $\begin{array}{l}\text { - Power analysis indicated that 6-12 calves per treatment } \\
\text { were needed to detect significant differences between } \\
\text { groups for salivary cortisol and tail flick data - only six calves } \\
\text { per group were assessed for behavioural indicators of pain } \\
\text { so this may have reduced the ability to detect differences } \\
\text { - Administration of intratesticular sham block could have } \\
\text { artificially increased scrotal inflammation } \\
\text { - Behavioural scoring did not take place until at least } 5 \text { hours } \\
\text { after castration so acute behavioural changes may have } \\
\text { occurred and been missed } \\
\text { - No Cl stated }\end{array}$ \\
\hline
\end{tabular}

Moya et al. (2014)

\begin{tabular}{|c|c|}
\hline Population: & Angus bull calves aged approximately 7 months old (Canada) \\
\hline Sample size: & 150 calves \\
\hline Intervention details: & $\begin{array}{l}\text { Experiment } \mathbf{1} \text { ( } \mathbf{n = 7 7 )} \\
\text { Treatment groups (exact numbers of animals in each group not } \\
\text { given) } \\
\text { 1. No castration and physiological solution (CT-PS) } \\
\text { 2. No castration and ketoprofen (CT-KP) } \\
\text { 3. Surgical castration and physiological solution (SU-PS) } \\
\text { 4. Surgical castration and ketoprofen (SU-KP) } \\
\text { 5. Band castration and physiological solution (BA-PS) } \\
\text { 6. Band castration and ketoprofen (BA-KP) } \\
\text { Doses and administration } \\
\text { - Ketoprofen ( } 3 \mathrm{mg} / \mathrm{kg} \text { ) - single intramuscular injection in the } \\
\text { neck } 30 \text { minutes prior to castration } \\
\text { Physiological solution - equivalent amount to ketoprofen } \\
\quad \text { administered intramuscularly into the neck } 30 \text { minutes } \\
\text { before castration } \\
\text { Experiment } 2 \text { ( } n=73 \text { ) } \\
\text { Treatment groups identical to Experiment } 1 \\
\text { Doses and administration } \\
\text { - Ketoprofen ( } 3 \mathrm{mg} / \mathrm{kg} \text { ) - intramuscular injections in the neck } \\
\quad 30 \text { minutes before castration and } 1,2,3,4,5 \text { and } 6 \text { days } \\
\text { - postcastration } \\
\text { Physiological solution (saline) - equivalent amount to } \\
\text { ketoprofen administered intramuscularly into the neck } 30\end{array}$ \\
\hline
\end{tabular}




\begin{tabular}{|c|c|}
\hline & $\begin{array}{l}\text { minutes before castration and } 1,2,3,4,5 \text { and } 6 \text { days } \\
\text { postcastration }\end{array}$ \\
\hline Study design: & Controlled trial \\
\hline Outcome studied: & $\begin{array}{l}\text { Physiological indicators of pain/inflammation } \\
\text { - Objective assessment of scrotal temperature (using } \\
\text { thermographic imaging) and salivary cortisol concentrations } \\
\text { before and after castration } \\
\text { - Objective assessment of blood parameters (WBC count and } \\
\mathrm{N}: \mathrm{L} \text { ) after castration } \\
\text { - Objective assessment of weight before and for several } \\
\text { weeks after castration to obtain ADG } \\
\text { Behavioural indicators of pain } \\
\text { Objective assessment of feed intake and feeding behaviour } \\
\text { (timeframe measurements were taken in not stated) }\end{array}$ \\
\hline $\begin{array}{l}\text { Main findings: } \\
\text { (relevant to PICO question): }\end{array}$ & $\begin{array}{l}\text { - Blood and saliva samples were taken from a subset of } \\
\text { animals ( } n=23 \text { and } n=24 \text { respectively); these groups } \\
\text { contained calves from each treatment group } \\
\text { - Salivary cortisol tended ( } p=0.08 \text { ) to be lower in KP calves } \\
\text { than PS calves at } 5 \text { hours postcastration in experiment } 1 \\
\text { - No other significant effect of ketoprofen on physiological or } \\
\text { behavioural indications of pain in either experiment }\end{array}$ \\
\hline Limitations: & $\begin{array}{l}\text { - Limited behavioural assessment } \\
\text { Blood and saliva samples were only taken from a subset of } \\
\text { animals so there may have been inadequate statistical } \\
\text { power and associations may have been missed (no power } \\
\text { calculations are reported) } \\
\text { - } \quad \text { o } \mathrm{Cl} \text { reported } \\
\text { - Some results were trends and not statistically significant } \\
\text { Ketoprofen chiral inversion varies between individuals } \\
\text { depending partially on age and physiological status - } \\
\text { variation in inversion contributes to variation in } \\
\text { pharmacological properties and ability to inhibit } \\
\text { prostaglandin production so ketoprofen may not be an } \\
\text { effective analgesic in certain populations }\end{array}$ \\
\hline
\end{tabular}

Olson et al. (2016)

\begin{tabular}{|r|l|}
\hline Population: & Holstein bull calves aged 4-5 months old (Canada) \\
\hline Sample size: & 60 calves \\
\hline Intervention details: & Treatment groups ( $\mathbf{n}=\mathbf{1 5}$ for all groups) \\
& 1. Band castration with saline (BS) \\
& 2. Band castration with meloxicam (BM) \\
& 3. Surgical castration with saline (SS) \\
& 4. Surgical castration with meloxicam (SM) (one animal was \\
& removed from this group due to surgical complications \\
& requiring further care) \\
& Power calculations were carried out to determine the number of \\
& calves needed to obtain meaningful results \\
\hline
\end{tabular}




\begin{tabular}{|c|c|}
\hline & $\begin{array}{l}\text { Doses and administration } \\
\text { - Meloxicam }(1 \mathrm{mg} / \mathrm{kg}) \text { - administered orally approx. } 2 \text { hours } \\
\text { before castration } \\
\text { - Saline }(1 \mathrm{ml} \text { per } 15 \mathrm{~kg}) \text { - administered orally approx. } 2 \text { hours } \\
\text { before castration } \\
\text { Persons who prepared syringes, treated the animals and carried out } \\
\text { randomisation were not blinded } \\
\text { Persons who cared for the calves, collected blood, downloaded data, } \\
\text { behaviour scored the calves, evaluated inflammation and analysed } \\
\text { plasma were blinded }\end{array}$ \\
\hline Study design: & Randomised controlled trial \\
\hline Outcome studied: & $\begin{array}{l}\text { Physiological markers of pain/inflammation } \\
\text { - Objective assessment of heart rate 2-4, 6-8 and 8-10 hours } \\
\text { after castration } \\
\text { Objective assessment of blood parameters (cortisol and } \\
\text { substance P concentrations) before and after castration and } \\
\text { diameter of mid-scrotum tissue in surgically castrated calves } \\
\text { - Subjective assessment of scrotal swelling (scoring system) in } \\
\text { band castrated calves } \\
\text { Behavioural markers of pain } \\
\text { - Objective assessment of standing and lying behaviour, lying } \\
\text { bouts and duration, motion index, step count using } \\
\text { accelerometer and tail movement using tail pedometers } \\
\text { before and after castration } \\
\text { - Subjective assessment (by blinded observers) using a visual } \\
\text { analogue scale after castration - scoring belly kicking, } \\
\text { stretching, changing of position, arching of back, standing } \\
\text { alone in the pen, looking at/licking the scrotum, frequent tail } \\
\text { flicking, lack of alertness and lack of interest in feed/water }\end{array}$ \\
\hline $\begin{array}{l}\text { Main findings: } \\
\text { (relevant to PICO question): }\end{array}$ & 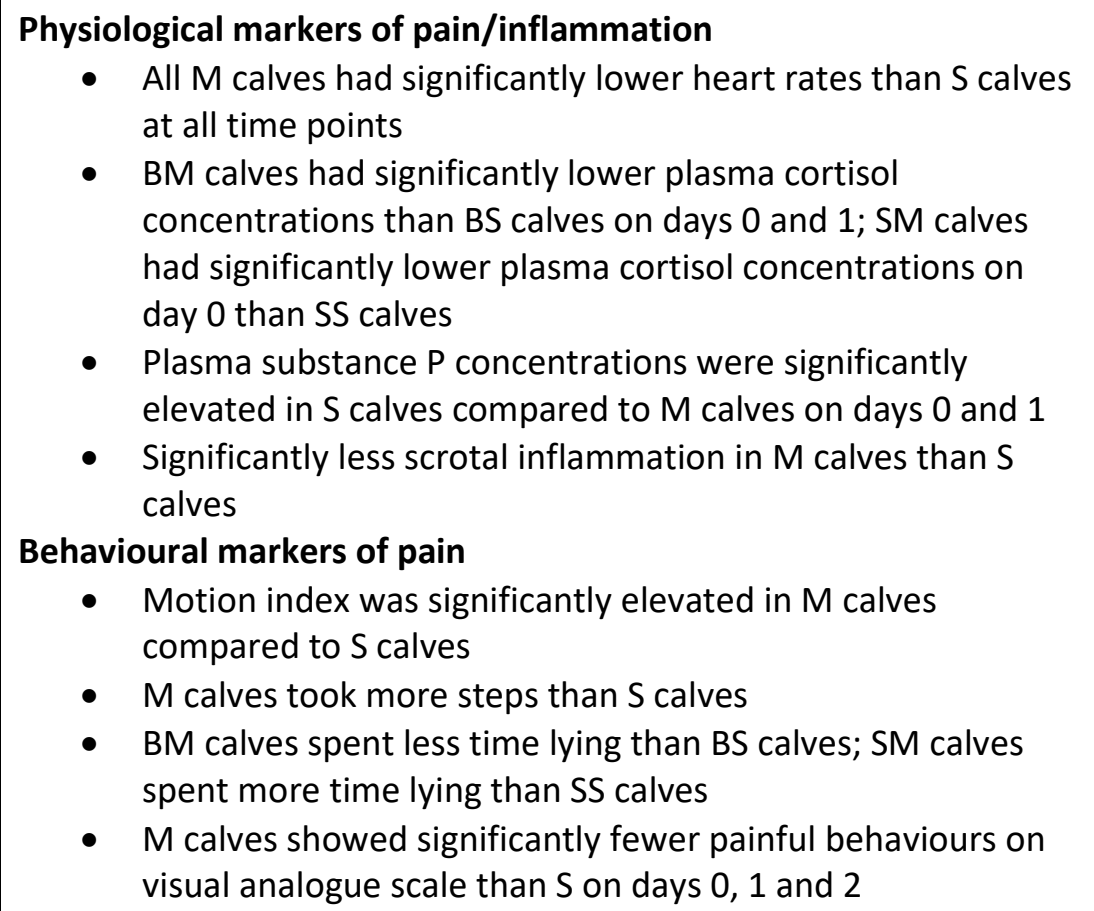 \\
\hline
\end{tabular}




\begin{tabular}{|l|l|}
\hline Limitations: & $\begin{array}{l}\text { - Cl not stated for individual results } \\
\end{array}$ \\
& $\begin{array}{l}\text { - Only } 10 \text { hours of heart rate data was analysed as no data } \\
\text { could be obtained for many animals past } 10 \text { hours }\end{array}$ \\
& $\begin{array}{l}\text { No comparison to uncastrated treated and non-treated } \\
\text { controls }\end{array}$ \\
\hline
\end{tabular}

Paull et al. (2015)

\begin{tabular}{|c|c|}
\hline Population: & Angus bull calves aged 7-9 weeks (Australia) \\
\hline Sample size: & 40 calves \\
\hline Intervention details: & $\begin{array}{l}\text { Treatment groups ( } \mathbf{n}=\mathbf{1 0} \text { per group) } \\
\text { 1. Sham control (C) } \\
\text { 2. Band castration with flunixin (BF) } \\
\text { 3. Band castration with flunixin and diclofenac (BFD) } \\
\text { 4. Band castration with saline (BS) } \\
\text { BFD group was not included in evidence appraisal as diclofenac is } \\
\text { not licenced in cattle in the UK } \\
\text { Doses and administration } \\
\text { - Flunixin - } 200 \mathrm{mg} \text { for BF group, administered } \\
\text { subcutaneously around the neck of the scrotum } \\
\text { immediately after band application } \\
\text { - Saline - } 6 \mathrm{~mL} \text { administered subcutaneously around the neck } \\
\text { of the scrotum immediately after band application }\end{array}$ \\
\hline Study design: & Randomised controlled trial \\
\hline Outcome studied: & $\begin{array}{l}\text { Physiological indicators of pain/inflammation } \\
\text { - Objective assessment of blood parameters (WBC count, N:L, } \\
\text { plasma cortisol and haptoglobin concentrations) and rectal } \\
\text { temperature before and after castration } \\
\text { - Objective measurement of weight before and after } \\
\text { castration to obtain ADG } \\
\text { Behavioural indicators of pain } \\
\text { Subjective assessment by blinded observers using video footage of } \\
\text { active pain avoidance behaviours (attempts to stand and lie, } \\
\text { restlessness, kicking/foot stamping, wound licking, stretching) and } \\
\text { postural behaviours (lying, standing and walking behaviours) for } 12 \\
\text { hours after castration }\end{array}$ \\
\hline $\begin{array}{l}\text { Main findings: } \\
\text { (relevant to PICO question): }\end{array}$ & $\begin{array}{l}\text { Physiological indicators of pain/inflammation } \\
\text { - BF calves had higher ADG at the end of week } 3 \text { than BS } \\
\text { calves } \\
\text { - No significant effects of flunixin on plasma cortisol or } \\
\text { haptoglobin concentrations, rectal temperature, WBC count } \\
\text { or N:L } \\
\text { Behavioural indicators of pain } \\
\text { - BF calves showed significantly more active pain avoidance } \\
\text { behaviours than C and BS calves } \\
\text { BF and BS calves both showed more postural pain } \\
\text { behaviours than C calves but there was no significant } \\
\text { difference between BF and BS calves }\end{array}$ \\
\hline
\end{tabular}




\begin{tabular}{|c|c|}
\hline Limitations: & $\begin{array}{l}\text { - One SC calf and one BS calf were omitted from behavioural } \\
\text { analysis due to }>50 \% \text { postural data being missing due to } \\
\text { rainfall making footage difficult to view, reducing the sample } \\
\text { size } \\
\text { - } \quad \text { Rainfall may have made behavioural analysis more difficult } \\
\text { even in calves which had more complete data recorded } \\
\text { - Experiment was carried out in five cohorts due to logistical } \\
\text { limitations; there were statistically significant differences in } \\
\text { normal standing, ventral lying and normal walking behaviour } \\
\text { between cohorts (thought to be due to differences in } \\
\text { weather conditions) which may have masked more subtle } \\
\text { treatment-associated behavioural changes } \\
\text { - Flunixin can be irritating to tissues so is normally } \\
\text { administered intravenously - iatrogenic scrotal irritation } \\
\text { may have caused increased pain avoidance behaviours in the } \\
\text { BF calves } \\
\text { - Only subjective measurement of pain-related behaviour } \\
\text { Power calculations not reported so sample size may have } \\
\text { been too small to accurately detect all differences } \\
\text { No Cl reported }\end{array}$ \\
\hline
\end{tabular}

Petherick et al. (2014a) and Petherick et al. (2014b) (two papers relating to the same experiment: one for behavioural findings and one for physiological findings)

\begin{tabular}{|c|c|}
\hline Population: & $\begin{array}{l}\text { Purebred Brahman bulls aged } 7-10 \text { months old (Australia) } \\
\text { (A second experiment was carried out using } 22-25 \text { month old } \\
\text { Brahman bulls but this was not included in the evidence appraisal as } \\
\text { it was not directly relevant to the PICO question) }\end{array}$ \\
\hline Sample size: & 32 calves \\
\hline Intervention details: & $\begin{array}{l}\text { Treatment groups ( } \mathbf{n}=\mathbf{8} \text { per group) } \\
\text { 1. Band castration with saline (BS) } \\
\text { 2. Band castration with ketoprofen (BK) } \\
\text { 3. Surgical castration with saline (SS) } \\
\text { 4. Surgical castration with ketoprofen (SK) } \\
\text { Groups were assigned based on liveweight, scrotal circumference } \\
\text { and flight speed } \\
\text { Doses and administration } \\
\text { - Ketoprofen ( } 3 \mathrm{mg} / \mathrm{kg} \text { ) - injected intramuscularly into the } \\
\text { - } \text { anterior neck immediately before castration } \\
\text { confirmed that this is a typographical error and the correct } \\
\text { - dose administered was } 3 \mathrm{mg} / \mathrm{kg} \\
\text { - Saline (0.9\% sodium chloride) - injected in the same location } \\
\text { as ketoprofen and at an equivalent volume }\end{array}$ \\
\hline Study design: & Controlled trial \\
\hline Outcome studied: & $\begin{array}{l}\text { Physiological indicators of pain } \\
\text { - Objective assessment of blood parameters (packed cell } \\
\text { volume (PCV), total protein, creatine kinase, plasma cortisol } \\
\text { and haptoglobin concentrations) immediately before and for }\end{array}$ \\
\hline
\end{tabular}




\begin{tabular}{|c|c|}
\hline & $\begin{array}{l}\text { up to } 7 \text { hours after castration and weight for several weeks } \\
\text { after castration } \\
\text { - Subjective assessment of scrotal healing (scoring system) } \\
\text { after castration } \\
\text { Behavioural indications of pain } \\
\text { Subjective assessment by a blinded observer of behaviour } \\
\text { postcastration, including standing and lying behaviour, ruminating } \\
\text { behaviour, walking behaviour, feeding and drinking, tail flicking and } \\
\text { tucking, leg lifting and kicking }\end{array}$ \\
\hline $\begin{array}{l}\text { Main findings: } \\
\text { (relevant to PICO question): }\end{array}$ & $\begin{array}{l}\text { Physiological indicators of pain } \\
\text { - No significant differences between calves given ketoprofen } \\
\text { and control calves in cortisol or haptoglobin concentration } \\
\text { - } \text { BK and SK calves had higher creatine kinase concentrations } \\
\text { than the control groups at } 7 \text { hours postcastration and } \\
\text { exceeded reference intervals } \\
\text { - SK calves had lowest total protein levels and PCV, suggesting } \\
\text { ketoprofen increased blood loss } \\
\text { - No effect of ketoprofen on overall liveweight change or } \\
\text { Behavioural indicators of pain } \\
\text { - SK calves spent more time feeding than SS calves } \\
\text { - Ketoprofen-treated calves tended to show fewer tail } \\
\text { movements than saline-treated calves }\end{array}$ \\
\hline Limitations: & $\begin{array}{l}\text { - No comparison to uncastrated control calves administered } \\
\text { ketoprofen and saline } \\
\text { - Ketoprofen takes some time to provide analgesia so more } \\
\text { behavioural effects may have been seen if there was a } \\
\text { longer time between administration and castration } \\
\text { (however the authors did this intentionally to mimic what is } \\
\text { likely to occur in industry) } \\
\text { - There were occasions when the blinded observer was } \\
\text { effectively unblinded due to the presence of blood on the } \\
\text { hindlegs of some surgically castrated bulls } \\
\text { - Only subjective measurement of pain-related behaviour } \\
\text { - Small sample size may reduce reliability of data (no power } \\
\text { calculations reported) } \\
\text { - No Cl reported }\end{array}$ \\
\hline
\end{tabular}

Repenning et al. (2013)

\begin{tabular}{|r|l|}
\hline Population: & $\begin{array}{l}\text { Experiment 1: Angus and Charolais crossbred bull calves (approx. } 8 \\
\text { months old) (USA) } \\
\text { Experiment 2: Hereford, Angus and Hereford x Angus bulls (age not } \\
\text { given) (USA) }\end{array}$ \\
\hline Sample size: & $\begin{array}{l}\text { Experiment 1: } 127 \text { calves } \\
\text { Experiment 2: } 30 \text { calves }\end{array}$ \\
\hline Intervention details: & $\begin{array}{l}\text { Interventions were the same in Experiments } 1 \text { and } 2 \\
\text { Treatment groups } \\
\text { 1. Band castration with placebo (BAND) }\end{array}$ \\
\hline
\end{tabular}




\begin{tabular}{|c|c|}
\hline & $\begin{array}{l}\text { 2. Band castration with meloxicam (BAND-MEL) } \\
\text { 3. Sham castration with placebo (SHAM) } \\
\text { Numbers of animals in specific groups were not given } \\
\text { Dose and administration } \\
\text { - Meloxicam - orally administered (encapsulated in porcine } \\
\text { gelatin bolus) at } 1.0,0.5 \text { and } 0.5 \mathrm{mg} / \mathrm{kg} \text { on days }-1,0 \\
\text { (concurrent with castration) and } 1 \text { respectively } \\
\text { - Placebo - empty porcine gelatin capsule }\end{array}$ \\
\hline Study design: & Randomised controlled trial \\
\hline Outcome studied: & $\begin{array}{l}\text { Experiment } 1 \\
\text { Physiological indicators of pain/inflammation } \\
\text { Daily weighing (objective measurement) before and after castration } \\
\text { to determine ADG } \\
\text { Behavioural indicators of pain } \\
\text { - Subjective assessment of response to restraint (chute score) } \\
\text { before, during and after castration; standing, walking, lying, } \\
\text { eating and drinking behaviours before and after castration } \\
\text { using video footage by blinded observers } \\
\text { - Objective assessment of exit velocity after taking chute } \\
\text { score (before and after castration) } \\
\text { Experiment } 2 \\
\text { Physiological indicators of pain/inflammation } \\
\text { - Objective assessment of blood substance P concentration } \\
\quad \text { and rectal temperature before and after castration; } \\
\text { - Weight was also measured to obtain ADG but time points for } \\
\text { this are not stated } \\
\text { Behavioural indicators of pain } \\
\text { Subjective assessment of response to restraint (chute score) before, } \\
\text { during and after castration }\end{array}$ \\
\hline $\begin{array}{l}\text { Main findings: } \\
\text { (relevant to PICO question): }\end{array}$ & $\begin{array}{l}\text { Experiment } 1 \\
\text { - No difference in ADG or chute score between BAND-MEL } \\
\text { and BAND groups calves; SHAM calves had higher ADG than } \\
\text { both groups of banded calves } \\
\text { - Meloxicam treatment had no effect on pen feed bunk } \\
\text { behaviour within } 120 \text { minutes of castration } \\
\text { - Smaller proportion of BAND-MEL calves standing } \\
\text { immediately postcastration than BAND calves but greater } \\
\text { proportion of BAND-MEL calves standing on days 1-3 than } \\
\text { BAND calves } \\
\text { Experiment } 2 \\
\text { Physiological indicators of pain/inflammation } \\
\text { - Plasma substance P concentrations did not differ across } \\
\text { treatments } \\
\text { BAND-MEL calves had higher rectal temperatures than } \\
\text { BAND calves } \\
\text { Behavioural indicators of pain } \\
\text { No difference in chute score or ADG between BAND-MEL calves and } \\
\text { BAND calves }\end{array}$ \\
\hline
\end{tabular}




\begin{tabular}{|l|l|l|}
\hline Limitations: & - Very small sample size for Experiment 2 may have limited \\
& detection of associations (no power calculations reported) \\
& $\begin{array}{l}\text { - No Cl reported } \\
\text { - No age given for calves in Experiment } 2\end{array}$ \\
& $\begin{array}{l}\text { - Collection intervals may have been too wide to detect acute } \\
\text { changes in substance P associated with treatment (samples } \\
\text { taken on days } 0 \text { immediately before castration, } 1 \text { and 7) }\end{array}$ \\
\hline
\end{tabular}

\begin{tabular}{|r|l|}
\hline Roberts et al. (2015) \\
\hline Population: & Crossbred yearling beef bulls (USA) \\
\hline Sample size: & 30 calves \\
\hline Intervention details: & $\begin{array}{c}\text { Treatment groups } \\
\text { 1. Sham castration (CON) } n=10\end{array}$ \\
& $\begin{aligned} \text { 2. Surgical castration without meloxicam (CAS) } n=10 \\
\text { 3. Surgical castration with meloxicam (MEL) } n=10\end{aligned}$ \\
& $\begin{aligned} \text { Doses and administration } \\
\text { Seloxicam (1 mg/kg) administered orally as a bolus directly into the } \\
\text { Sumen via oesophageal intubation concurrently with castration }\end{aligned}$ \\
\hline Outcome studied: & Physiological indicators of pain/inflammation \\
& Randomised controlled trial \\
& Objective assessment of blood parameters (CBC, serum haptoglobin \\
& and cortisol concentrations and proinflammatory cytokines (TNF-a, \\
& IFN-g)) and rectal temperature before and after castration
\end{tabular}

\begin{tabular}{|c|c|}
\hline $\begin{array}{l}\text { Main findings: } \\
\text { (relevant to PICO question): }\end{array}$ & $\begin{array}{l}\text { - CAS calves had higher cortisol concentrations than MEL and } \\
\text { CON groups (CON was lowest) until } 4 \text { hours postcastration } \\
\text { - CAS calves also had secondary cortisol peak at } 2.5 \text { hours } \\
\text { which MEL group did not; MEL group showed drop in } \\
\text { cortisol levels at } 2 \text { hours } \\
\text { - No difference in cortisol levels between CAS and MEL calves } \\
\text { at } 4 \text { hours postcastration } \\
\text { - CAS calves had highest haptoglobin levels } \\
\text { - MEL calves had lower haptoglobin levels than CON group - } \\
\text { also had least change in haptoglobin compared to baseline } \\
\text { values } \\
\text { - MEL calves had higher rectal temperature than other groups } \\
\text { CAS calves had higher WBC counts than MEL and CON } \\
\text { groups }\end{array}$ \\
\hline Limitations: & $\begin{array}{l}\text { - Sample size may have been too small to detect all } \\
\text { associations (no power analysis reported) } \\
\text { - No } \mathrm{Cl} \text { reported } \\
\text { - Relatively high inter-assay coefficient of variation for } \\
\text { cytokine assessment }(<18.1 \% \text { ) which may have masked } \\
\text { some treatment effects } \\
\text { - Only physiological markers are assessed which are relatively } \\
\text { non-specific and are often due to inflammation rather than } \\
\text { pain - no assessment of behavioural indicators of pain } \\
\text { - Control groups were not given a placebo }\end{array}$ \\
\hline
\end{tabular}




\begin{tabular}{|c|c|}
\hline Population: & $\begin{array}{l}\text { Angus } x \text { Hereford male calves aged approximately } 8-10 \text { months } \\
\text { (USA) }\end{array}$ \\
\hline Sample size: & 194 calves ( 152 bull calves and 42 steers) \\
\hline Intervention details: & $\begin{array}{l}\text { Treatment groups (exact numbers of calves per group not given) } \\
\text { 1. Castrated within } 48 \text { hours of birth, i.e. steers at the time of } \\
\text { the experiment (CON) } \\
\text { 2. Surgically castrated on day } 0 \text { without meloxicam (SUR) } \\
\text { 3. Surgically castrated on day } 0 \text { with meloxicam (SUR + MEL) } \\
\text { 4. Band castrated on day } 0 \text { without meloxicam (BAN) } \\
\text { 5. Band castrated on day } 0 \text { with meloxicam (BAN + MEL) } \\
\text { Dosage and administration } \\
\text { Meloxicam ( } 1 \mathrm{mg} / \mathrm{kg} \text { ) administered orally as tablets within a gelatin } \\
\text { capsule concurrent with castration }\end{array}$ \\
\hline Study design: & Randomised controlled trial \\
\hline Outcome studied: & $\begin{array}{l}\text { Physiological indicators of pain/inflammation } \\
\text { - Objective assessment of serum haptoglobin concentration } \\
\text { (from a subset of } 150 \text { calves representative of all } \\
\text { treatments) at the time of castration and after castration } \\
\text { - Weight (measured before and after castration) to assess } \\
\text { growth performance } \\
\text { Behavioural indicators of pain } \\
\text { Objective assessment of standing and lying behaviour, number of } \\
\text { steps taken and motion index using accelerometers before and after } \\
\text { castration (using the same } 150 \text { calves used for serum haptoglobin } \\
\text { assessment) }\end{array}$ \\
\hline $\begin{array}{l}\text { Main findings: } \\
\text { (relevant to PICO question): }\end{array}$ & $\begin{array}{l}\text { Physiological indicators of pain/inflammation } \\
\text { - Tendency ( } p=0.07 \text { ) for MEL calves to have higher final } \\
\text { bodyweight than SUR or BAN calves; also overall increased } \\
\text { ADG in MEL calves compared to SUR or BAN calves } \\
\text { - Meloxicam had no effect on serum haptoglobin } \\
\text { concentration on day } 1 \\
\text { - On day } 4 \text { the SUR calves had significantly higher serum } \\
\text { haptoglobin than any other group, suggesting that } \\
\text { meloxicam may reduce surgical pain } \\
\text { - Meloxicam administration did not reduce haptoglobin } \\
\text { concentrations in band castrated calves } \\
\text { Behavioural indicators of pain } \\
\text { - Meloxicam treatment decreased motion index and } \\
\text { decreased the number of steps taken compared to } \\
\text { unmedicated castrated calves } \\
\text { - Generally surgically castrated calves stood more than band } \\
\text { castrated calves } \\
\text { SUR + MEL calves had more lying bouts than SUR calves } \\
\text { (standing thought to be associated with pain following } \\
\text { surgical castration) } \\
\text { BAN + MEL calves had fewer lying bouts than BAN calves } \\
\text { (lying thought to be associated with pain following band } \\
\text { castration) }\end{array}$ \\
\hline
\end{tabular}




\begin{tabular}{|l|l|}
\hline Limitations: & $\begin{array}{l}\text { Only subsets of animals (150) were used to collect blood and } \\
\text { behavioural data (the same animals were used for both), } \\
\text { reducing sample size }\end{array}$ \\
& $\begin{array}{l}\text { Quite limited behavioural and physiological indicators } \\
\text { investigated }\end{array}$ \\
- & ADG and growth performance data between groups cannot \\
be accurately directly compared as different calf cohorts \\
were given slightly different growth implants; growth \\
implants are also not used in the UK which may make \\
growth data less relevant to UK industry \\
- BAN and SUR calves were not given a placebo \\
- Cl not reported
\end{tabular}

\begin{tabular}{|c|c|}
\hline \multicolumn{2}{|l|}{ Sutherland et al. (2018) } \\
\hline Population: & Angus calves aged 3 months old (New Zealand) \\
\hline Sample size: & 60 calves \\
\hline Intervention details: & $\begin{array}{l}\text { Treatment groups ( } \mathbf{n}=\mathbf{2 0} \text { per group) } \\
\text { 1. Ring castration without meloxicam (RING) } \\
\text { 2. Ring castration with meloxicam (RING }+ \text { BUCC) } \\
\text { 3. Handled to mimic castration only (CON) } \\
\text { Random allocation of RING and RING + BUCC groups and heifers } \\
\text { used for CON group } \\
\text { Doses and administration } \\
\text { Meloxicam administered buccally }(5 \mathrm{~mL} \text { at } 10 \mathrm{mg} / \mathrm{mL} \text { ) immediately } \\
\text { before castration }\end{array}$ \\
\hline Study design: & Randomised controlled trial \\
\hline Outcome studied: & $\begin{array}{l}\text { Behavioural indicators of pain } \\
\text { Subjective assessment using video footage by a blinded observer of } \\
\text { behaviours after castration including standing, walking and lying } \\
\text { behaviours, head flicking, kicking, stomping, tail wagging and } \\
\text { ruminating (intra-observer reliability }=82-100 \% \text { ) }\end{array}$ \\
\hline $\begin{array}{l}\text { Main findings: } \\
\text { (relevant to PICO question): }\end{array}$ & $\begin{array}{l}\text { Behavioural indicators of pain } \\
\text { - RING + BUCC calves tended }(p=0.085) \text { to ruminate more } \\
\text { and had more bouts of standing stretched than RING calves } \\
\text { RING and RING + BUCC calves spent more time standing and } \\
\text { showed more lying bouts, abnormal walking bouts, kicks and } \\
\text { tail flicks than CON calves, i.e. meloxicam administration did } \\
\text { not reduce pain behaviours } \\
\text { - No other significant differences between RING and RING + } \\
\text { BUCC calves }\end{array}$ \\
\hline Limitations: & $\begin{array}{l}\text { - Meloxicam dose was not calculated by weight for individual } \\
\text { calves - according to the datasheet (myHealthbox) the } \\
\text { correct dose is } 0.5 \mathrm{mg} / \mathrm{kg} \text { and as mean calf weight was } 111.7 \\
\mathrm{~kg} \text { the calves were underdosed } \\
\text { - No placebo used for calves not given meloxicam } \\
\text { - One calf was excluded from data collection in the RING } \\
\text { group as it had already been castrated }\end{array}$ \\
\hline
\end{tabular}




\begin{tabular}{|l|l|}
\hline - Only behavioural indicators of pain were measured and data \\
was only collected until 3 hours postcastration so more \\
chronic pain behaviours could not be observed \\
- Only subjective measurement of pain-related behaviour \\
- $\quad$ Female calves were used as the control group so some \\
differences between CON and other groups may be affected \\
by sex differences \\
The calves were separated from their dams for the first time \\
for the study so stress caused by separation may have \\
caused behavioural changes which may have overridden \\
pain-related changes \\
Wide range of intra-observer reliability for behavioural \\
assessment may have masked some treatment effects \\
No Cl or power analyses reported
\end{tabular}

Ting et al. (2003)

\begin{tabular}{|c|c|}
\hline Population: & Holstein x Friesian bulls aged 11 months old (Ireland) \\
\hline Sample size: & 50 calves \\
\hline Intervention details: & $\begin{array}{l}\text { Treatment groups ( } \mathrm{n}=\mathbf{1 0} \text { per group) } \\
\text { 1. Untreated control (C) } \\
\text { 2. Surgical castration at } 0 \text { minutes (S) } \\
\text { 3. Surgical castration after ketoprofen administration at -20 } \\
\text { minutes (SK1) } \\
\text { 4. Surgical castration after ketoprofen administration at -20 } \\
\text { and } 0 \text { minutes (SK2) } \\
\text { 5. Surgical castration after ketoprofen administration at -20 } \\
\text { and } 0 \text { minutes with further ketoprofen given at } 24 \text { hours } \\
\text { (SK3) } \\
\text { Doses and administration } \\
\text { Ketoprofen was administered intravenously (IV) through an } \\
\text { indwelling jugular catheter at the following doses: } \\
\text { - SK1: } 3 \mathrm{mg} / \mathrm{kg} \\
\text { - SK2: } 1.5 \mathrm{mg} / \mathrm{kg} \text { at both time points } \\
\text { - SK3: } 1.5 \mathrm{mg} / \mathrm{kg} \text { at -20 and } 0 \text { minutes and } 3 \mathrm{mg} / \mathrm{kg} \text { at } 24 \\
\text { hours } \\
\text { Animals in the S group were given an equivalent volume of } 0.9 \% \\
\text { saline solution }\end{array}$ \\
\hline Study design: & Randomised controlled trial \\
\hline Outcome studied: & $\begin{array}{l}\text { Physiological indicators of pain/inflammation } \\
\text { - Objective assessment of blood parameters (cortisol, } \\
\text { haptoglobin, total antioxidant status, IFN-g, fibrinogen and } \\
\text { routine haematology) rectal temperature and dry matter } \\
\text { intake (DMI) before and after castration } \\
\text { - Calves were weighed before and after castration to } \\
\text { determine ADG } \\
\text { Behavioural indicators of pain } \\
\text { Subjective assessment by a single observer of standing, lying, } \\
\text { feeding and ruminating behaviour after castration }\end{array}$ \\
\hline
\end{tabular}




\begin{tabular}{|c|c|}
\hline $\begin{array}{l}\text { Main findings: } \\
\text { (relevant to PICO question): }\end{array}$ & $\begin{array}{l}\text { Physiological indicators of pain/inflammation } \\
\text { - Ketoprofen administration failed to prevent cortisol increase } \\
\text { O.25-1.5 hours following castration } \\
\text { - SK calves had lower mean plasma cortisol concentrations } \\
\text { than S group 2-6 hours postsurgery; no difference between } \\
\text { SK groups } \\
\text { - SK1 and SK2 calves had reduced mean plasma haptoglobin } \\
\text { concentrations compared to S animals on day } 3 \\
\text { - K calves had higher plasma fibrinogen on day } 7 \text { than C or S } \\
\text { groups } \\
\text { - ADG was lower in S, SK2 and SK3 calves compared to C } \\
\text { calves with SK1 values intermediate between C and other } \\
\text { groups } \\
\text { Behavioural indicators of pain } \\
\text { SK1, SK2 and SK3 calves demonstrated reduced combined } \\
\text { abnormal standing activities compared to S calves, which } \\
\text { had increased combined abnormal standing activities than C } \\
\text { calves } \\
\text { - No difference in feeding activities } \\
\text { Ketoprofen administration increased incidence of total } \\
\text { rumination compared to S group to similar levels as seen in } \\
\text { C group }\end{array}$ \\
\hline Limitations: & $\begin{array}{l}\text { - Small sample size per treatment may have made } \\
\text { associations more difficult to detect (no power analyses } \\
\text { reported) } \\
\text { - } \quad \text { No } \mathrm{Cl} \text { reported } \\
\text { - } \text { Relatively high inter-assay coefficient of variation for high } \\
\text { concentration cortisol assays (19.0\%) which may have } \\
\text { masked some treatment effects } \\
\text { - The behavioural observer was not blinded } \\
\text { - Behavioural indicators of pain/inflammation are only } \\
\text { assessed subjectively }\end{array}$ \\
\hline
\end{tabular}

Van Der Saag et al. (2018)

\begin{tabular}{|c|c|}
\hline Population: & Unweaned Angus bull calves aged 2-4 months old (Australia) \\
\hline Sample size: & 50 calves \\
\hline Intervention details: & $\begin{array}{l}\text { Treatment groups ( } \mathbf{n}=\mathbf{1 0} \text { per group) } \\
\text { 1. Sham castration (SHAM) } \\
\text { 2. Surgical castration (C) } \\
\text { 3. Surgical castration with preoperative administration of } \\
\text { buccal meloxicam (CBM) } \\
\text { 4. Surgical castration with postoperative application of topical } \\
\text { anaesthetic (CTA) } \\
\text { 5. Surgical castration with preoperative meloxicam and } \\
\text { postoperative local anaesthetic (CBMTA) } \\
\text { CTA and CBMTA groups were not included in the evidence appraisal } \\
\text { as they are not directly related to the PICO question }\end{array}$ \\
\hline
\end{tabular}




\begin{tabular}{|c|c|}
\hline & $\begin{array}{l}\text { Doses and administration } \\
\text { Meloxicam }(0.5 \mathrm{mg} / \mathrm{kg}) \text { - gel formulation administered buccally } \\
\text { adjacent to upper molar teeth } 25 \text { minutes before castration }\end{array}$ \\
\hline Study design: & Randomised controlled trial \\
\hline Outcome studied: & $\begin{array}{l}\text { Physiological indicators of pain/inflammation } \\
\text { - Objective assessment of weight before and after castration } \\
\text { to determine ADG } \\
\text { - Objective assessment of scrotal diameter and maximum } \\
\text { scrotal temperature after castration } \\
\text { - Subjective assessment of wound morphology score } \\
\text { following castration } \\
\text { Behavioural indicators of pain } \\
\text { Subjective assessment of walking, standing, lying, postural, eating } \\
\text { and drinking behaviours by blinded observers using video footage } \\
\text { for } 5 \text { hours following castration }\end{array}$ \\
\hline $\begin{array}{l}\text { Main findings: } \\
\text { (relevant to PICO question): }\end{array}$ & $\begin{array}{l}\text { Physiological indicators of pain/inflammation } \\
\text { - No effect of treatment on scrotal diameter, wound } \\
\text { - } \text { morphology score or ADG } \\
\text { cower maximum scrotal temperatures in CBM calves than C } \\
\text { Behavioural indicators of pain } \\
\text { - C calves tended to spend more time walking with a stiff gait } \\
\text { - } \text { than CBM calves } \\
\text { C calves showed more foot stamps than CBM calves }\end{array}$ \\
\hline Limitations: & $\begin{array}{l}\text { - Relatively small sample size per treatment group. May have } \\
\text { made associations more difficult to detect (no power } \\
\text { analyses reported) } \\
\text { - } \quad \text { No Cl reported } \\
\text { - } \quad \text { No assessment of APPs or blood parameters e.g. cortisol } \\
\text { - } \text { sehaviour was only assessed for } 5 \text { hours following castration } \\
\text { measured; no information about chronic pain due to } \\
\text { inflammation, which NSAIDs are more suited to treating } \\
\text { - Several behaviours used in the ethogram could not be } \\
\text { included in statistical analysis due to low frequency which } \\
\text { may have reduced the sensitivity of pain detection } \\
\text { - } \quad \text { Only subjective measurement of pain-related behaviour } \\
\text { - Calves were unweaned so separation from their mothers } \\
\text { during castration and sampling may have attenuated pain } \\
\text { responses by distracting them from pain, reducing } \\
\text { behavioural pain signs (overall limited expression of } \\
\text { behavioural pain indicators during observation period) }\end{array}$ \\
\hline
\end{tabular}

Webster et al. (2013)

Population: Weaned Holstein-Friesian bull calves aged 2-3 months old (USA)

Sample size: 30 calves 


\begin{tabular}{|c|c|}
\hline Intervention details: & $\begin{array}{l}\text { Treatment groups (exact numbers per group not given) } \\
\text { 1. Surgical castration control (CC) } \\
\text { 2. Surgical castration with local anaesthetic (LA) } \\
\text { 3. Surgical castration with flunixin meglumine (FM) } \\
\text { 4. Surgical castration with local anaesthetic and flunixin } \\
\text { meglumine (LA + FM) } \\
\text { 5. Sham control (SC) } \\
\text { LA and LA + FM groups were not included in the evidence appraisal } \\
\text { as they are not directly relevant to the PICO question } \\
\text { Doses and administration } \\
\text { - Flunixin meglumine ( } 1.1 \mathrm{mg} / \mathrm{kg} \text { ) administered IV via jugular } \\
\text { catheter } 20 \text { minutes before castration } \\
\text { CC and SC calves received } 2 \mathrm{~mL} \text { IV 0.9\% sodium chloride } \\
\text { - Solution instead of flunixin meglumine } \\
\text { Scrotal skin and testes of FM, CC and SC calves were handled } \\
\text { to simulate lidocaine administration without needle } \\
\text { insertion }\end{array}$ \\
\hline Study design: & Randomised controlled trial \\
\hline Outcome studied: & $\begin{array}{l}\text { Physiological indicators of pain/inflammation } \\
\text { Objective assessment of plasma cortisol concentration before and } \\
\text { after castration } \\
\text { Behavioural indicators of pain } \\
\text { - Objective assessment of feed intake and weight (used to } \\
\text { determine ADG) before and after castration } \\
\text { - Subjective assessment of video footage of feeding, lying, } \\
\text { standing and postural behaviours, foot stamping, leg lifting, } \\
\text { head turning and scrotal licking for up to } 8 \text { hours } \\
\text { postcastration }\end{array}$ \\
\hline $\begin{array}{l}\text { Main findings: } \\
\text { (relevant to PICO question): }\end{array}$ & $\begin{array}{l}\text { Physiological indicators of pain/inflammation } \\
\text { - FM calves showed a rapid sharp increase in plasma cortisol } \\
\text { concentration which peaked at } 15 \text { minutes and returned to } \\
\text { baseline by } 45 \text { minutes postcastration; lower than CC calves } \\
\text { at } 45 \text { minutes } \\
\text { - No difference in integrated cortisol response between FM } \\
\text { and SC calves; integrated cortisol response was higher for } \\
\text { calves castrated without drugs } \\
\text { Behavioural indicators of pain } \\
\text { - No effect of flunixin on feed intake or bodyweight gain } \\
\text { - Graphically FM appears to reduce crouching, leg lifting to } \\
\text { groom and statue standing frequency compared to CC calves } \\
\text { but this is not reported as statistically significant } \\
\text { - Most behaviours for drug treated calves were not } \\
\text { significantly different for CC or SC controls and no recorded } \\
\text { significant differences between FM calves and CC or SC } \\
\text { calves for specific behaviours }\end{array}$ \\
\hline Limitations: & $\begin{array}{l}\text { - Small sample size may have made it difficult to detect } \\
\text { associations (no power analyses reported) } \\
\text { - Relatively high inter-assay coefficient of variation for high } \\
\text { concentration cortisol assay (17.1\%) } \\
\text { - Cl not reported }\end{array}$ \\
\hline
\end{tabular}


- High variability between individual calves for lying and standing behaviour

- Behaviour was mainly assessed subjectively rather than e.g. using an accelerometer/pedometer to record standing, walking and lying data as in other studies (although behaviours were well defined)

- Only plasma cortisol concentration was used as a physiological assessment of pain; cortisol is not pain-specific and can be affected by several other factors inc. handling stress

- Plasma cortisol concentration and behaviour were only assessed up to 8 hours postcastration so more chronic changes would not have been observed

\section{Appraisal, application and reflection}

All 20 studies appraised were controlled trials, of which 17 were randomised, indicating a relatively high level of evidence. No relevant meta-analyses were found and narrative reviews were excluded due to being widely focused and not showing reproducible search strategies. All studies appraised compared NSAID administration to a control calf castrated without NSAIDs; several studies also included non-castrated or sham-castrated calves to provide a baseline against which pain indicators could be compared. Some studies further improved this protocol by including both medicated and unmedicated sham groups, allowing more accurate differentiation between behavioural and physiological indicators of handling stress versus pain and reducing over-interpretation. Of the studies appraised, 15 included the use of a placebo (saline or lactated Ringer's solution) in approximately equal volume to the NSAID in unmedicated calves to quantify and control for discomfort associated with drug administration. Eleven studies involved blinding, either of personnel recording behavioural observations or measuring physiological pain indicators or both. This was particularly important in behavioural observation to reduce bias as far as possible. However, due to the experimental nature it was sometimes difficult to blind observers, as e.g. surgically castrated calves can be visually differentiated from band castrated calves in the period immediately following castration; Petherick et al. (2014a; and 2014b) also reported that some surgically castrated calves had blood on their hindlimbs, making them easy to identify. Several studies also analysed behavioural parameters using video footage rather than via direct contact with the calves, reducing the likelihood of observer effects on behaviour.

The studies appraised showed mixed results for the efficacy of NSAIDs alone at reducing signs of postcastration pain, although overall 13 out of the 20 studies showed some improvement in pain indicators following NSAID administration. It is important to note that pain is inherently subjective and is therefore difficult to assess objectively; physiological indicators of pain can be measured but some lack specificity to pain alone and can be affected by other factors, e.g. cortisol may increase due to handling stress (Grandin, 1997). Similarly, APPs e.g. SAA and haptoglobin, are indirectly associated with pain through their inflammatory role; as NSAIDs reduce pain associated with inflammation, APP concentrations can be used as a measure of NSAID efficacy but they are not pain-specific. Substance $P$ is involved in nociception, and has been shown to decrease with meloxicam administration following dehorning (Coetzee et al., 2012; and Allen et al., 2013). Substance P concentrations were measured in five studies, of which only two (Meléndez et al., 2018b; and Olson et al., 2016) found a significant decrease following NSAID administration. However, the three studies which found no effect on plasma substance P (Kleinhenz et al., 2018; Meléndez et al., 2018a; and Repenning et al., 2013) used sampling intervals which may have been too wide to detect any changes.

Behaviours such as lesion-licking, foot-stamping, tail flicking and changes in standing and lying behaviour may be more pain-specific (Millman, 2013) than physiological markers, but are more difficult to objectively assess. Several studies used a visual analogue scale to make subjective assessment of pain-related behaviours more repeatable, however in several cases the visual analogue scale was only used to assess intra-castration pain which was beyond the scope of this Knowledge Summary. Objective measurement of behavioural parameters 
can be obtained using devices e.g. pedometers, accelerometers and pressure mats, which was done by 11 studies. However, these devices generally only collect walking, standing and lying data and not discrete and more pain-specific behaviours such as those described above. Other behavioural changes measured objectively include exit velocity as calves leave the chute and feed intake, however again these are not very pain-specific.

Pain-associated behaviours vary between reports; some authors suggest cattle in pain take fewer steps and show more lying behaviour (Currah et al., 2009; and Laurence et al., 2018), whereas Ting et al. (2003) found that the incidence of combined lying postures in castrated calves was significantly lower than uncastrated calves. This is further confounded by different castration methods causing different behavioural changes: surgical castration may increase standing time and band castration may increase lying time (Roberts et al., 2018). Behavioural indicators of pain may also be difficult to detect as cattle are prey animals and therefore mask pain signs (Laurence et al., 2018), especially in older calves unused to human contact. Due to the limitations in both physiological and behavioural pain assessment methods, it is therefore preferable to use both together to obtain the most accurate results; of the studies appraised, all included both physiological and behavioural parameters in their analysis except Roberts et al., (2015) who only investigated physiological parameters and Sutherland et al., (2018) who only investigated behavioural parameters. Roberts et al. (2015) reported reduced plasma cortisol and haptoglobin concentrations following meloxicam administration so it would have been interesting to see if this coincided with behavioural changes as well. Conversely, Sutherland et al. (2018) reported no improvement in pain behaviours following meloxicam administration. However, meloxicam was under-dosed; the datasheet states a dose of $0.5 \mathrm{mg} / \mathrm{kg}$ and each calf was administered $5 \mathrm{ml}$ (at $10 \mathrm{mg} / \mathrm{ml}$ ), but as mean calf weight was $111.7 \mathrm{~kg}$ the mean dose should have been $5.6 \mathrm{ml}$. Behaviour was also only observed for 3 hours postcastration, so improvements may have been seen with a higher dose and a longer observation period, especially as band castration as used in this study may cause more chronic than acute pain (Petherick et al., 2014a; and 2014b).

Castration method may also affect the type of pain experienced and therefore the analgesic ability of NSAIDs. Within the same method the exact way castration is carried out may differ, e.g. differences in blunt dissection in surgical castration between individual veterinary surgeons and individual calves depending on anatomic variations and personal technique. Different individual calves may also have different pain tolerances (Stafford \& Mellor, 2005); these differences in both pain tolerance and infliction make it difficult to accurately compare the studies appraised. Of the five studies which showed improvement in both physiological and behavioural pain indicators, three investigated surgical castration (Laurence et al., 2018; Meléndez et al., 2018a; and Ting et al., 2003) and two investigated surgical and band castration together (Meléndez et al., 2018b; and Olson et al., 2016). Conversely, of the seven studies which showed no significant improvement in pain, four only investigated band castration (Daniel et al., 2020; Paull et al., 2015; Repenning et al., 2013; and Sutherland et al., 2018). It is worth noting that of all the studies appraised, only these four studies investigated band castration alone. This could suggest that band castration is less amenable to pain relief through NSAIDs than surgical methods, although further work would be required to investigate this. Meléndez et al. (2018b) reported that knife castration was associated with the most behavioural pain indicators, in contrast with Petherick et al. (2014a; and 2014b) who reported more longer-term pain behaviours and less NSAID efficacy in band castration; this may be related to the age of calf used as band castration is thought to be less painful in younger calves than older calves due to smaller testicular size. Olson et al. (2016) and Roberts et al. (2018) found that meloxicam treated band castrated calves spent less time lying than their control counterparts, while meloxicam treated surgically castrated calves spent more time lying than their control counterparts, supporting the idea that different castration methods induce different types of pain and suggesting that meloxicam has some effective analgesic ability for both castration methods.

Pain perception in calves may be influenced by age. Bretschneider (2005) reported that castration closely following birth reduces weight loss associated with castration compared to calves castrated later in life; however weight changes are not specific to pain, as reduced weight gain can be influenced by both inappetence caused by pain and reduced testosterone secretion reducing muscle mass, and pain can also 
motivate calves to suckle more (Meléndez et al., 2018b), increasing weight gain. Bretschneider (2005) also reported that the cortisol response of calves castrated at 6 months or younger tended to be lower than that of older calves and hypothesised that this was related to increased trauma and discomfort due to increased testicular size. However, Stafford \& Mellor (2005) reported relatively similar peaks in plasma cortisol concentration for calves aged $6,21,42$ days, 2-4 months and 5.5 months by castration method used. Despite these possible differences in pain response depending on age, studies investigating calves of all ages up to 1 year were included in the evidence appraisal, as differences in pain response are likely not so significant that they make these studies completely inapplicable to UK practice. Only one study (Meléndez et al., 2018b) investigated a cohort where all calves were below the UK legal age limit for castration without anaesthesia and found meloxicam administration reduced both physiological and behavioural pain signs. Three other studies used calf cohorts where some individuals may have been within the legal age limit (Gellatly et al., 2021; Marti et al., 2018; and Paull et al., 2015) (2 months, 2 months and 7-9 weeks old respectively) and found no improvement in pain indicators following NSAID administration, suggesting that calf age is not the most important factor in NSAID efficacy.

The time at which NSAIDs are administered relative to castration is also likely to affect analgesic efficacy. 12 studies involved NSAID administration before castration and of these, four showed reduced physiological and behavioural indicators of pain and a further four resulted in improvements in either physiological or behavioural indicators. NSAID administration concurrently with castration (Kleinhenz et al., 2018; Repenning et al., 2013; Roberts et al., 2015; Roberts et al., 2018; and Ting et al., 2003) reduced both physiological and behavioural signs in one study (Ting et al., 2003) and one of physiological or behavioural indicators in a further three. Postoperative NSAID administration (Daniel et al., 2020; Laurence et al., 2018; Paull et al., 2015; Repenning et al., 2013; and Ting et al., 2003) appears to be the least effective, with only two studies reporting improvement in pain signs (Laurence et al., 2018; and Ting et al., 2003); however, it is important to note that these studies both incorporated NSAID administration at several different time points. This could be related to NSAID mechanism of action, as analgesia is provided through COX inhibition reducing prostaglandin synthesis (Day et al., 1987); administration before a painful stimulus may reduce total prostaglandins further than administration after the stimulus when prostaglandin synthesis has already occurred. Ting et al. (2003) reported that calves given either $3 \mathrm{mg} / \mathrm{kg}$ ketoprofen 20 minutes before castration or $1.5 \mathrm{mg} / \mathrm{kg} 20$ minutes before followed by $1.5 \mathrm{mg} / \mathrm{kg}$ concurrent to castration had reduced mean plasma haptoglobin concentration relative to castrated control calves on day 3 , but this was the main significant difference between ketoprofen treated calves, suggesting that time of administration is not the main factor in analgesic effect. Similarly, Laurence et al. (2018) reported that calves administered $0.5 \mathrm{mg} / \mathrm{kg}$ meloxicam 30 minutes before castration were more active after castration than unmedicated controls, and that postoperative meloxicam administration at the same dose resulted in calves resting less than controls. These behavioural changes are similar and both meloxicam treated calves had significantly lower plasma cortisol concentrations postcastration than control calves, suggesting both pre- and postoperative meloxicam have some analgesic effect. Repenning et al. (2013) also investigated the effect of several meloxicam doses $(1.0,0.5 \mathrm{and} 0.5 \mathrm{mg} / \mathrm{kg}$ on days $-1,0$ (concurrent with castration) and 1 respectively) and found no significant improvement in pain. This may be because band castration was used, which is thought to cause more chronic pain than the surgical castration used by Laurence et al. (2018) and Ting et al. (2003).

Several different NSAIDs were used in the studies appraised. Only NSAIDs licenced for use in cattle in the UK at the time of writing (meloxicam, ketoprofen, carprofen and flunixin) (Veterinary Medicines Directorate, 2020) were included; of these, 13 studies investigated meloxicam (of which eight reported some benefit), four investigated ketoprofen (of which one, Ting et al. (2003), reported improvements in physiological and behavioural parameters and two, Petherick et al. (2014a; and 2014b), reported behavioural improvements) and three investigated flunixin (of which two, Kleinhenz et al. (2018) and Webster et al. (2013) reported reduced cortisol concentrations). Paull et al. (2015) reported that calves treated with $200 \mathrm{mg}$ flunixin showed significantly more pain avoidance behaviours than both calves castrated without flunixin and uncastrated calves. This was the only study which found increased pain following NSAID administration and is thought to be due to tissue irritation due to subcutaneous injection of flunixin into the scrotum. No studies investigating 
carprofen or directly comparing different NSAIDs were found. Based on the studies appraised, it appears that meloxicam has the best analgesic efficacy for postcastration pain. Ketoprofen has been reported to undergo variable chiral inversion in cattle depending on age and physiological status and these changes are thought to alter its ability to inhibit prostaglandin production (Moya et al., 2014); these changes are not currently well understood, making the efficacy of ketoprofen quite variable. Flunixin does not appear to reliably significantly reduce postcastration pain; Kleinhenz et al. (2018) and Webster et al. (2013) both reported reduced cortisol responses following flunixin administration, but no studies found any improvement in behavioural indicators of pain. However, these results must be taken with caution due to the small number of studies appraised.

The final confounding factor affecting NSAID efficacy is dose and administration. The most common dose for meloxicam was $0.5 \mathrm{mg} / \mathrm{kg}$ (seven out of 13 papers investigating meloxicam), and of these five papers found some improvement in pain signs following meloxicam administration. Interestingly, Daniel et al. (2020) used a dose of $2.0 \mathrm{mg} / \mathrm{kg}$ meloxicam but found no significant improvement in pain, however this study investigated band castration, which according to the appraised evidence was less amenable to pain relief via NSAIDs. Additionally, limited physiological indicators were assessed and behavioural changes were not clearly interpreted; meloxicam treated calves took fewer steps than unmedicated calves on days 7 and 15 which is reported to possibly suggest pain amelioration as the behavioural change occurred the day after meloxicam administration. However other authors (Olson et al., 2016; and Laurence et al., 2018) report that cattle in pain take fewer steps and the uncastrated controls in the Daniel et al. (2020) study took more steps, suggesting that the absence of pain increases step count. Ketoprofen was generally administered at a total dose of 3 $\mathrm{mg} / \mathrm{kg}$ and flunixin was administered at variable doses of $3.33 \mathrm{mg} / \mathrm{kg}$ (Kleinhenz et al., 2018), $200 \mathrm{mg}$ (Paull et al., 2015) and $1.1 \mathrm{mg} / \mathrm{kg}$ (Webster et al., 2013). It is also worth noting that in on-farm situations calf weight may be estimated, resulting in incorrect dose calculations and therefore ineffective analgesia, as in Sutherland et al. (2018).

It is also possible that NSAIDs generally do not provide adequate analgesia for invasive, painful procedures such as castration as NSAID analgesia displays a ceiling effect (Ong et al., 2007). Combinations of lidocaine and meloxicam or ketoprofen have been reported to be very efficacious in reducing signs of postoperative pain, including the initial acute spike in cortisol associated with castration (Meléndez et al., 2018c; and Webster et al., 2013). However, injection of local anaesthetic into the testes can be painful in itself (Stafford \& Mellor, 2005) so more research into this area may be required.

Although not all of the studies appraised are in agreement about the efficacy of NSAIDs in reducing signs of pain postcastration, 13 out of the 20 studies found some benefit to NSAID use and only seven found no benefit, suggesting that on balance NSAID administration is likely to reduce postcastration pain by some degree. Of the NSAIDs investigated, meloxicam appears to be the most effective, although further work in this area is required. Further work is also required to investigate the effect of NSAIDs along with local anaesthetic administered 10-15 minutes prior to castration, as this appears to be the most effective way to mitigate both acute and more chronic pain associated with castration.

\section{Methodology Section}

\begin{tabular}{|c|c|}
\hline \multicolumn{2}{|l|}{ Search Strategy } \\
\hline $\begin{array}{r}\text { Databases searched and dates } \\
\text { covered: }\end{array}$ & $\begin{array}{l}\text { CAB Abstracts on OVID Platform }(1973-2021) \\
\text { PubMed NCBI }(1973-2021) \\
\text { Web of Science Core Collection }(1900-2021)\end{array}$ \\
\hline Search terms: & $\begin{array}{l}\text { CAB Abstracts: } \\
\text { (calf OR calves OR bull*) } \\
\text { (castrat* OR gonadect* OR neuter* OR burdizzo OR orchi*) } \\
\text { (NSAID* OR "non-steroidal” OR “non steroidal" OR “anti- } \\
\text { inflammatory" OR "anti inflammatory" OR meloxicam OR flunixin OR }\end{array}$ \\
\hline
\end{tabular}




\begin{tabular}{|l|l|}
\hline $\begin{array}{l}\text { ketoprofen OR carprofen) } \\
\text { (pain* OR discomfort OR comfort* OR behavio*) }\end{array}$ \\
$\begin{array}{l}\text { PubMed: } \\
\text { (((calf OR calves OR bull*) AND (castrat* or gonadect* OR neuter* } \\
\text { OR burdizzo OR orchi*)) AND (NSAID* OR "non-steroidal" OR "non } \\
\text { steroidal" OR "anti-inflammatory" OR "anti inflammatory" OR } \\
\text { meloxicam OR flunixin OR ketoprofen OR carprofen)) AND (pain* OR } \\
\text { discomfort OR comfort* OR behavio*) }\end{array}$ \\
$\begin{array}{l}\text { Web of Science: } \\
\text { ALL FIELDS: (calf OR calves OR bull*) AND ALL FIELDS: (castrat* OR } \\
\text { gonadect* OR neuter* OR burdizzo OR orchi*) AND ALL FIELDS: } \\
\text { (NSAID OR "non-steroidal" OR "non steroidal" OR "anti- } \\
\text { inflammatory" OR "anti inflammatory" OR meloxicam OR flunixin OR } \\
\text { ketoprofen OR carprofen) AND ALL FIELDS: (pain* OR discomfort OR } \\
\text { comfort* OR behavio*) }\end{array}$ \\
\hline Dates searches performed: & \begin{tabular}{l} 
O8 Apr 2021 \\
\hline
\end{tabular} \\
\hline
\end{tabular}

\section{Exclusion / Inclusion Criteria}

Only NSAIDs licenced for use in cattle in the UK were included in the search strategy and in appraised papers

Exclusion: Non-English language study, not associated with the effect of NSAIDs on postcastration pain in calves, all treatment groups given anaesthetic, intervention not compared to control measure, conference proceedings, no full-text article

Inclusion: Controlled trials, investigating effect of NSAIDs on postcastration pain in calves, compared to control measure

\begin{tabular}{|c|c|c|c|c|c|c|}
\hline \multicolumn{7}{|c|}{ Search Outcome } \\
\hline Database & $\begin{array}{c}\text { Number } \\
\text { of } \\
\text { results }\end{array}$ & $\begin{array}{l}\text { Excluded - } \\
\text { Non-English } \\
\text { language } \\
\text { publication }\end{array}$ & $\begin{array}{l}\text { Excluded - } \\
\text { Not directly } \\
\text { related to } \\
\text { PICO question }\end{array}$ & $\begin{array}{l}\text { Excluded - } \\
\text { Intervention not } \\
\text { compared to } \\
\text { control measure }\end{array}$ & $\begin{array}{l}\text { Excluded - } \\
\text { Conference } \\
\text { proceedings }\end{array}$ & $\begin{array}{c}\text { Total } \\
\text { relevant } \\
\text { papers }\end{array}$ \\
\hline $\begin{array}{l}\mathrm{CAB} \\
\text { Abstracts }\end{array}$ & 72 & 1 & 44 & 3 & 4 & 20 \\
\hline PubMed & 42 & 1 & 24 & 2 & 0 & 15 \\
\hline $\begin{array}{l}\text { Web of } \\
\text { Science }\end{array}$ & 133 & 0 & 105 & 2 & 7 & 19 \\
\hline Total relevar & pers wh & duplicates r & oved & & & 20 \\
\hline
\end{tabular}




\section{CONFLICT OF INTEREST}

The author declares no conflicts of interest.

The author would like to thank Professor Simon Priestnall and Bridget Sheppard for their guidance and assistance with this article, as well as Clare Boulton for obtaining papers which were not available.

\section{REFERENCES}

1. Allen, K.A., Coetzee, J.F., Edwards-Callaway, L.N., Glynn, H., Dockweiler, J., KuKanich, B., Lin, H., Wang, C., Fraccaro, E., Jones, M. \& Bergamasco, L. (2013). The effect of timing of oral meloxicam administration on physiological responses in calves after cautery dehorning with local anesthesia. Journal of Dairy Science. 96(8), 5194-5205. DOI: https://doi.org/10.3168/ids.2012-6251

2. Bretschneider, G. (2005). Effects of age and method of castration on performance and stress response of beef male cattle: A review. Livestock Production Science. 97(2-3), 89-100.

DOI: https://doi.org/10.1016/i.livprodsci.2005.04.006

3. BVA. (2017). Analgesia in Calves. Available at: https://www.bva.co.uk/media/1172/analgesia-incalves.pdf [Accessed 20 Nov 2020].

4. Coetzee, J.F., Mosher, R.A., KuKanich, B., Gehring, R., Robert, B., Reinbold, J.B. \& White, B.J. (2012). Pharmacokinetics and effect of intravenous meloxicam in weaned Holstein calves following scoop dehorning without local anesthesia. BMC Veterinary Research. 8. DOI: https://doi.org/10.1186/17466148-8-153

5. Cooper, R. (2016). Improving the welfare of calves at castration and disbudding / dehorning in the UK. Livestock. 21(2), 84-90. DOI: https://doi.org/10.12968/live.2016.21.2.84

6. Currah, J.M., Hendrick, S.H. \& Stookey, J.M. (2009). The behavioral assessment and alleviation of pain associated with castration in beef calves treated with flunixin meglumine and caudal lidocaine epidural anesthesia with epinephrine. Canadian Veterinary Journal. 50(4), 375-382.

7. Daniel, J.A., Crane, A., Krawczel, P.D., Coetzee, J.F. \& Whitlock, B.K. (2020). Effect of oral meloxicam administration on growth performance and behavior of pre-weaning age calves following band castration. Trans/ational Animal Science. 4(2), 1082-1090. DOI: https://doi.org/10.1093/tas/txaa021

8. Day, R.O., Graham, G.G., Williams, K.M., David Champion, G. \& de Jager, J. (1987). Clinical pharmacology of non-steroidal anti-inflammatory drugs. Pharmacology \& Therapeutics. 33(2-3), 383433. DOI: https://doi.org/10.1016/0163-7258(87)90072-6

9. Farm Animal Welfare Committee. (2019). FAWC Opinion on the Welfare of Cattle Kept for Beef Production. Available

at: https://assets.publishing.service.gov.uk/government/uploads/system/uploads/attachment data/fil e/902524/FAWC Opinion on the welfare of cattle kept for beef production.pdf [Accessed 8 Nov 2020].

10. Grandin, T. (1997). Assessment of stress during handling and transport. Journal of Animal Science. 75(1), 249-257. DOI: https://doi.org/10.2527/1997.751249x

11. Gellatly, D., Marti, S., Pajor, E.A., Meléndez, D.M., Moya, D., Janzen, E.D., Yang, X., Milani, M.R.M. \& Schwartzkopf-Genswein, K.S. (2021). Effect of a single subcutaneous injection of meloxicam on chronic indicators of pain and inflammatory responses in 2-month-old knife and band-castrated beef calves housed on pasture. Livestock Science. 244. DOI: https://doi.org/10.1016/i.livsci.2020.104305

12. Kleinhenz, M.D., Van Engen, N.K., Smith, J.S., Gorden, P.J., Ji, J., Wang, C., Perkins, S.C.B. \& Coetzee, J.F. (2018). The impact of transdermal flunixin meglumine on biomarkers of pain in calves when administered at the time of surgical castration without local anesthesia. Livestock Science. 212, 1-6. DOI: https://doi.org/10.1016/j.livsci.2018.03.016 
13. Laurence, M., Barnes, A., Collins, T., Hyndman, T. \& Musk, G.C. (2018). Assessing and mitigating postoperative castration pain in Bos indicus cattle. Animal Production Science. 58(5), 909-919.

DOI: https://doi.org/10.1071/AN16210

14. Marti, S., Meléndez, D.M., Pajor, E.A., Moya, D., Gellatly, D., Janzen, E.D. \& Schwartzkopf-Genswein, K.S. (2018). Effect of a single dose of subcutaneous meloxicam before knife castration alone or combined with hot-iron branding on scrotal healing, inflammatory response, and behaviour in 2-moold beef calves over 42 d post procedure. Canadian Journal of Animal Science. 99(1), 179-190. DOI: https://doi.org/10.1139/cjas-2018-0016

15. Meléndez, D.M., Marti, S., Pajor, E.A., Moya, D., Gellatly, D., Janzen, E.D. \& Schwartzkopf-Genswein, K.S. (2018a). Effect of subcutaneous meloxicam on indicators of acute pain and distress after castration and branding in 2-mo-old beef calves. Journal of Animal Science. 96(9), 3606-3621. DOI: https://doi.org/10.1093/ias/sky245

16. Meléndez, D.M., Marti, S., Pajor, E.A., Moya, D., Gellatly, D., Janzen, E.D. \& Schwartzkopf-Genswein, K.S. (2018b). Effect of a single dose of meloxicam prior to band or knife castration in 1-wk-old beef calves: I. Acute pain. Journal of Animal Science. 96(4), 1268-1280.

DOI: https://doi.org/10.1093/jas/sky034

17. Meléndez, D.M., Marti, S., Pajor, E.A., Sidhu, P.K., Gellatly, D., Moya, D., Janzen, E.D., Coetzee, J.F. \& Schwartzkopf-Genswein, K.S. (2018c). Effect of meloxicam and lidocaine administered alone or in combination on indicators of pain and distress during and after knife castration in weaned beef calves. PLOS ONE. 13(11). DOI: https://doi.org/10.1371/journal.pone.0207289

18. Millman, S.T. (2013). Behavioral Responses of Cattle to Pain and Implications for Diagnosis, Management, and Animal Welfare. Veterinary Clinics of North America: Food Animal Practice. 29(1), 47-58. DOI: https://doi.org/10.1016/i.cvfa.2012.11.007

19. Moya, D., González, L.A., Janzen, E., Caulkett, N.A., Fireheller, E. \& Schwartzkopf-Genswein, K.S. (2014). Effects of castration method and frequency of intramuscular injections of ketoprofen on behavioral and physiological indicators of pain in beef cattle. Journal of Animal Science. 92(4), 16861697. DOI: https://doi.org/10.2527/jas.2013-7298

20. myHealthbox. Ilium Buccalgesic OTM Datasheet. [online]. Available at: https://myhealthbox.eu/en/medicine/buccalgesicotm/3554994 [Accessed 16 Dec 2020].

21. Olson, M.E., Ralston, B., Burwash, L., Matheson-Bird, H. \& Allan, N.D. (2016). Efficacy of oral meloxicam suspension for prevention of pain and inflammation following band and surgical castration in calves. BMC Veterinary Research. 12(1). DOI: https://doi.org/10.1186/s12917-016-0735-3

22. Ong, C.K.S., Lirk, P., Tan, C.H. \& Seymour, R.A. (2007). An Evidence-Based Update on Nonsteroidal AntiInflammatory Drugs. Clinical Medicine and Research. 5(1), 19-34.

DOI: https://doi.org/10.3121/cmr.2007.698

23. Paull, D.R., Small, A.H., Lee, C., Labeur, L. \& Colditz, I.G. (2015). Effect of local infusion of NSAID analgesics administered alone or in combination on the pain associated with band castration in calves. Australian Veterinary Journal. 93(8), 271-277. DOI: https://doi.org/10.1111/avj.12348

24. Petherick, J.C., Small, A.H., Mayer, D.G., Colditz, I.G., Ferguson, D.M. \& Stafford, K.J. (2014a). A comparison of welfare outcomes for weaner and mature Bos indicus bulls surgically or tension band castrated with or without analgesia: 1. Behavioural responses. Applied Animal Behaviour Science. 157, 23-34. DOI: https://doi.org/10.1016/i.applanim.2014.05.003

25. Petherick, J.C., Small, A.H., Mayer, D.G., Colditz, I.G., Ferguson, D.M. \& Stafford, K.J. (2014b). A comparison of welfare outcomes for weaner and mature Bos indicus bulls surgically or tension band castrated with or without analgesia: 2 . Responses related to stress, health and productivity. Applied Animal Behaviour Science. 157, 35-47. DOI: https://doi.org/10.1016/j.applanim.2014.05.005

26. Repenning, P.E., Ahola, J.K., Callan, R.J., French, J.T., Giles, R.L., Bigler, B.J., Coetzee, J.F., Wulf, L.W., Peel, R.K., Whittier, J.C., Fox, J.T. \& Engle, T.E. (2013). Impact of oral meloxicam administration before and after band castration on feedlot performance and behavioral response in weanling beef bulls. Journal of Animal Science. 91(10), 4965-4974. DOI: https://doi.org/10.2527/ias.2012-6070 
27. Roberts, S.L., Hughes, H.D., Burdick Sanchez, N.C., Carroll, J.A., Powell, J.G., Hubbell, D.S. \& Richeson, J.T. (2015). Effect of surgical castration with or without oral meloxicam on the acute inflammatory response in yearling beef bulls. Journal of Animal Science. 93(8), 4123-4131.

DOI: https://doi.org/10.2527/ias.2015-9160

28. Roberts, S.L., Powell, J.G., Hughes, H.D. \& Richeson, J.T. (2018). Effect of castration method and analgesia on inflammation, behavior, growth performance, and carcass traits in feedlot cattle. Journal of Animal Science. 96(1), 66-75. DOI: https://doi.org/10.1093/ias/skx022

29. Van Der Saag, D., Lomax, S., Windsor, P.A., Taylor, C., Thomson, P., Hall, E. \& White, P.J. (2018). Effects of topical anaesthetic and buccal meloxicam on average daily gain, behaviour and inflammation of unweaned beef calves following surgical castration. Animal. 12(11), 2373-2381.

DOI: https://doi.org/10.1017/S1751731118000216

30. Stafford, K.J. \& Mellor, D.J. (2005). The welfare significance of the castration of cattle: A review. New Zealand Veterinary Journal. 53(5), 271-278. DOI: https://doi.org/10.1080/00480169.2005.36560

31. Sutherland, M.A., Bright, A.L. \& Schütz, K.E. (2018). Effect of a buccal meloxicam formulation on the behavioural response to ring castration of calves. Animal Production Science. 59(3), 564-569. DOI: https://doi.org/10.1071/AN17641

32. Ting, S., Earley, B. \& Crowe, M. (2003). Effect of repeated ketoprofen administration during surgical castration of bulls on cortisol, immunological function, feed intake, growth, and behavior. Journal of Animal Science. 81(5), 1253-1264. DOI: https://doi.org/10.2527/2003.8151253x

33. Veterinary Medicines Directorate. (2020). Product Information Database. [online]. Available at: https://www.vmd.defra.gov.uk/ProductInformationDatabase/Default.aspx [Accessed 8 Nov 2020].

34. Webster, H.B., Morin, D., Jarrell, V., Shipley, C., Brown, L., Green, A., Wallace, R. \& Constable, P.D. (2013). Effects of local anesthesia and flunixin meglumine on the acute cortisol response, behavior, and performance of young dairy calves undergoing surgical castration. Journal of Dairy Science. 96(10), 6285-6300. DOI: https://doi.org/10.3168/jds.2012-6238 


\section{EVIIDEFeE

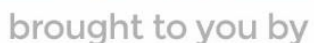 \\ RCVS KNOWLEDGE}

\section{Intellectual Property Rights}

Authors of Knowledge Summaries submitted to RCVS Knowledge for publication will retain copyright in their work, and will be required to grant RCVS Knowledge a non-exclusive license of the rights of copyright in the materials including but not limited to the right to publish, re-

publish, transmit, sell, distribute and otherwise use the materials in all languages and all media throughout the world, and to license or permit others to do so.

\section{Disclaimer}

Knowledge Summaries are a peer-reviewed article type which aims to answer a clinical question based on the best available current evidence. It does not override the responsibility

of the practitioner. Informed decisions should be made by considering such factors as individual clinical expertise and judgement along with patient's circumstances and owners' values. Knowledge Summaries are a resource to help inform and any opinions expressed within the Knowledge Summaries are the author's own and do not necessarily reflect the view of the RCVS Knowledge. Authors are responsible for the accuracy of the content. While the

Editor and Publisher believe that all content herein are in accord with current recommendations and practice at the time of publication, they accept no legal responsibility

for any errors or omissions, and make no warranty, express or implied, with respect to material contained within.

For further information please refer to our Terms of Use.

RCVS Knowledge is the independent charity associated with the Royal College of Veterinary Surgeons (RCVS). Our ambition is to become a global intermediary for evidence based veterinary knowledge by providing access to information

that is of immediate value to practicing veterinary professionals and directly contributes to evidence based clinical decision-making.

https://www.veterinaryevidence.org/

RCVS Knowledge is a registered Charity No. 230886.

Registered as a Company limited by guarantee in England and Wales No. 598443.

Registered Office: Belgravia House, 62-64 Horseferry Road, London SW1P 2AF

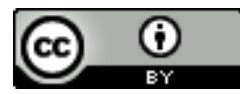

This work is licensed under a Creative Commons Attribution 4.0 International License 